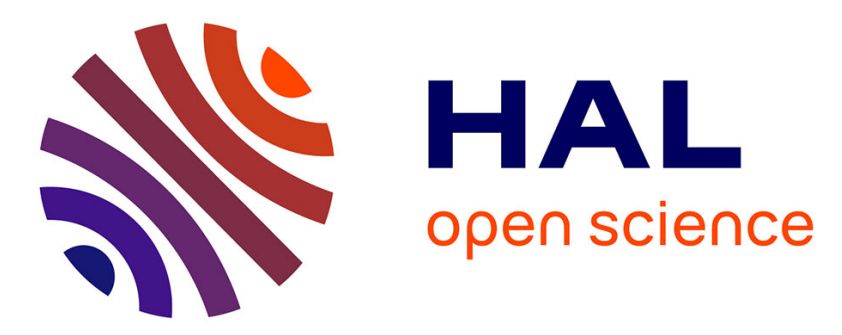

\title{
Epithelial-mesenchymal transition in cholangiocarcinoma: from clinical evidence to regulatory networks
}

Javier Vaquero, Nathalie Guedj, Audrey Clapéron, Thanh Huong Nguyen Ho-Bouldoires, Valérie Paradis, Laura Fouassier

\section{To cite this version:}

Javier Vaquero, Nathalie Guedj, Audrey Clapéron, Thanh Huong Nguyen Ho-Bouldoires, Valérie Paradis, et al.. Epithelial-mesenchymal transition in cholangiocarcinoma: from clinical evidence to regulatory networks. Journal of Hepatology, 2016, 10.1016/j.jhep.2016.09.010 . hal-01377000

\section{HAL Id: hal-01377000 https: / hal.sorbonne-universite.fr/hal-01377000}

Submitted on 6 Oct 2016

HAL is a multi-disciplinary open access archive for the deposit and dissemination of scientific research documents, whether they are published or not. The documents may come from teaching and research institutions in France or abroad, or from public or private research centers.
L'archive ouverte pluridisciplinaire HAL, est destinée au dépôt et à la diffusion de documents scientifiques de niveau recherche, publiés ou non, émanant des établissements d'enseignement et de recherche français ou étrangers, des laboratoires publics ou privés. 
Epithelial-mesenchymal transition in cholangiocarcinoma: from clinical evidence to regulatory networks

Javier Vaquero ${ }^{1,2}$, Nathalie Guedj ${ }^{3,4}$, Audrey Clapéron ${ }^{1}$, Thanh Huong Nguyen Ho-

Bouldoires ${ }^{1}$, Valérie Paradis ${ }^{3,4}$, and Laura Fouassier ${ }^{1}$

1-INSERM, Sorbonne Universités, UPMC Univ Paris 06, Centre de Recherche Saint-Antoine (CRSA), F-75012 Paris, France;

2-FONDATION ARC, F-94803 Villejuif, France;

3-Service d'Anatomie Pathologique Hôpital Beaujon, F-92110, Clichy, France;

4-INSERM, UMR 1149, Centre de Recherche sur l'Inflammation, F-75018, Paris, France.

\section{Corresponding author:}

Laura Fouassier, Ph.D.

INSERM UMR_S 938, Centre de Recherche Saint-Antoine (CRSA)

184 rue du Faubourg Saint-Antoine

75571 - Paris cedex 12, France

33698774001 (phone)

laura.fouassier@inserm.fr

Keywords: Cholangiocarcinoma, epithelial-mesenchymal transition, invasiveness, chemoresistance, tumor microenvironment.

Abbreviations: CAF, cancer-associated fibroblasts; CCA, cholangiocarcinoma; CSC, cancer stem cell; dCCA, distal CCA; DFS, disease free survival; eCCA, extrahepatic CCA; EMT, epithelial-mesenchymal transition; EMT-TFs, EMT-inducing transcription factors; HSCs, hepatic stellate cells; OS, overall survival; pCCA, perihilar CCA; TAM, tumor-associated macrophages. Words: 5349, Tables: 2 , Fi gures: 3

Conflict of interests: None to declare. 
Financial support: LF is supported by grants from Fondation de France $\left(\mathrm{N}^{\circ} 2014\right.$ 00047502) and La Ligue National contre le Cancer ( $\left.N^{\circ} \mathrm{RS} 14 / 75-112\right)$. JV is recipient of two following postdoctoral fellowships from the Spanish Association for the Study of the Liver (AEEH) and the Fondation ARC NPDF2014601431.

Authors' contributions: JV and AC contributed to outline and drafting of the review, intellectual content, critical revision and figure illustrations. NG and VP supervised content on human part, THHB provided critical revision and LF contributed to the conception of the paper, writing and revision of the manuscript. 


\section{Abstract}

Cholangiocarcinoma (CCA) is an aggressive tumor with a poor prognosis due to its late clinical presentation and the lack of effective non-surgical therapies. Unfortunately, most of the patients are not eligible for curative surgery owing to the presence of metastases at the time of diagnosis. Therefore, it is important to understand the steps leading to cell dissemination in patients with CCA. To metastasize from the primary site, cancer cells must acquire migratory and invasive properties by a cell plasticity-promoting phenomenon known as epithelial-mesenchymal transition (EMT). EMT is a reversible dynamic process by which epithelial cells gradually adopt structural and functional characteristics of mesenchymal cells, and has lately become a center of attention in the field of metastatic dissemination. In the present review, we aim to provide an extensive overview of the current clinical data and the prognostic value of different EMT markers that have been analyzed in CCA. We summarize all the regulatory networks implicated in EMT from the membrane receptors to the main EMT-inducing transcription factors (SNAIL, TWIST and ZEB). Furthermore, since a tumor is $\underline{\text { a complex structure not exclusively formed by tumor cells, we also address the prominent }}$ role of the main cell types of the desmoplastic stroma that characterizes CCA in the regulation of EMT. Finally, we discuss the therapeutic considerations and difficulties faced to develop an effective anti-EMT treatment due to the redundancies and bypasses among the pathways regulating EMT. 


\section{Key Point Box}

- EMT is an early event of metastasis that endows tumor cells with invasive properties enabling them to spread toward other territories.

- EMT contributes to CCA progression and chemoresistance.

- The three families of transcription factors that regulate epithelial and mesenchymal marker expression during EMT (SNAIL, TWIST and ZEB) contribute to CCA progression.

- Cells of CCA microenvironment, and not only cancer cells, lead to the activation of EMT.

- Targeting of EMT is challenging due to the redundancies and bypasses among EMTregulated pathways. 


\section{Introduction}

Cholangiocarcinoma (CCA) accounts for $3 \%$ of all gastrointestinal cancers and it is the second most common primary hepatic tumor after hepatocellular carcinoma $[1,2]$. CCA is composed of tumor cells exhibiting a phenotype of biliary epithelial cells, as well as nontumor cells, essentially myofibroblasts [3], and characterized by an aggressive behavior with early lymphatic and metastatic spread. CCA is subdivided into two main subclasses that differ in their anatomical presentation, natural history and treatment [4]. Intrahepatic CCA (iCCA) arises from small bile ducts and bile ductules whereas extrahepatic CCA (eCCA) originates from the hilum (perihilar CCA ( $\mathrm{pCCA})$ ) to the distal portion of large bile ducts (dCCA) [4]. The term CCA will be used when studies do not distinguish between iCCA and $\mathrm{pCCA} / \mathrm{dCCA}$. While eCCA incidence remains stable, an increase in the incidence of iCCA has been observed, without any clear explanation [5].

Patients with CCA display a poor prognosis due to its late diagnosis and lack of effective non-surgical curative therapies. Surgical resection is the only curative treatment, but it is only available for a small percentage of patients with early-stage disease, and only $20-30 \%$ of these patients survive after 5 years due to the high rate of recurrence after surgery $[6,7]$. Most of the patients are ineligible for curative surgery because of the presence of metastases at the time of diagnosis [8]. The only option for these patients is to undergo a palliative treatment with a combination of gemcitabine and platinum salt, the reference chemotherapy validated for advanced unresectable CCA $[8,9]$. Understanding the steps that lead to cell dissemination in patients with CCA is currently an important issue to be resolved in order to identify new therapeutic targets to prevent cancer progression and recurrence. During the past few years, epithelial-mesenchymal transition (EMT) has gained a lot of attention regarding metastatic dissemination. However, other mechanisms, such as exosomes released by different tumor cell types or the role played by circulating tumor cells, cannot be ruled out. 
EMT is a reversible dynamic process during which epithelial cells gradually adopt structural and functional characteristics of mesenchymal cells [10-13]. EMT is fundamental in several physiological processes, such as embryogenesis and wound healing. During the past decade EMT has been proven to be deeply involved in different pathological processes, including fibrosis development and cancer progression. More specifically, EMT is an early event of metastasis that is required for tumor cell migration and invasion from the primary tumor (Figure 1). Major EMT steps comprise modifications of gene expression allowing concurrently epithelial phenotype repression and mesenchymal phenotype activation [14, 15]. The first changes take place at the adherens junctions with a deregulation of two main components, E-cadherin and $\beta$-catenin. Tight junction disruption also occurs and leads to a loss of apical-basal polarity. One mechanism by which E-cadherin is down-regulated occurs via EMT-inducing transcription factors (EMT-TFs), which comprise three families: SNAIL, ZEB and TWIST. EMT-TFs primarily regulate E-cadherin expression by repressing its promoter, but they also regulate in a positive manner the expression of genes associated with mesenchymal phenotypes including $\mathrm{N}$-cadherin, vimentin, fibronectin, a-smooth muscle actin ( $\alpha-S M A)$ and matrix metalloproteinases (MMPs) $[15,16]$. Then, a reorganization of the epithelial actin cytoskeleton takes place with the formation of several migratory structures and the expression of MMPs to degrade the extracellular matrix (ECM). Thus, the acquisition of a mesenchymal-like phenotype endows the tumor cells with invasive properties, enabling them to spread toward other territories.

This review aims to give a complete overview on the knowledge gained so far on EMT in CCA and its regulation. In addition, contribution of the microenvironment cells in the induction of tumor cell plasticity and therapeutic consideration of EMT will be discussed.

\section{Clinical evidence of EMT in cholangiocarcinoma (Table1)}

\section{Disruption of intercellular junctions}

E-cadherin is a calcium-dependent cell-cell adhesion glycoprotein that constitutes with $\beta$ catenin the backbone of adherens junctions and plays a key role in the maintenance of 
epithelium integrity [17]. E-cadherin deregulation affects this integrity constituting one of the major hallmarks of EMT. While E-cadherin is localized at the plasma membrane in healthy biliary epithelium, its down-regulation and/or ectopic localization, i.e. cytoplasmic internalization, have been reported in malignant cholangiocytes [18-37]. Genetic mutations and epigenetic silencing through promoter hypermethylation of the E-cadherin gene $(\mathrm{CDH} 1)$ are among the mechanisms that account for the down-regulation of E-cadherin $[30,33,38]$. A reduction of E-cadherin immunostaining was observed in $16.5-82.1 \%$ of iCCA [21, 24-26, $29,31,32,34-36]$ and eCCA $[18,37,39,40]$. Although, down-regulation of E-cadherin in iCCA has been correlated with poor tumor differentiation, tumor size, advanced pTNM stage, intrahepatic metastasis and lymph node metastasis [25, 26, 29, 31, 32, 36], its prognostic value is still controversial. Ryu et al., did not find any impact of E-cadherin expression on overall survival (OS) or disease free survival (DFS) [24] whereas other groups demonstrated that E-cadherin loss was significantly associated with these parameters and was an independent prognostic factor $[25,32,36]$. In eCCA, patients with weak E-cadherin expression displayed lower survival rate than patients with high E-cadherin expression [18] and was also an independent prognostic factor [40].

During EMT, E-cadherin is disordered at the expense of the expression of another cadherin named $\mathrm{N}$-cadherin that is normally expressed by mesenchymal cells. This switch operates in both types of CCA in which an up-regulation of $\mathrm{N}$-cadherin expression has been observed $[18,25,34,40,41]$. Increasing $\mathrm{N}$-cadherin expression has been associated with lower OS in both CCA subclasses $[25,40]$ and is an independent unfavorable prognostic factor in eCCA [40].

$\beta$-catenin is retained at the membrane by $E$-cadherin while in cell cytoplasm $\beta$-catenin is recognized by the destruction complex wherein it is phosphorylated by GSK-3ß (Glycogen Synthase Kinase-3 $\beta$ ). Thus, GSK-3 $\beta$ prevents $\beta$-catenin cytoplasm accumulation and consequently its translocation to the nucleus. When $\beta$-catenin reaches the nucleus, it associates with DNA-binding transcription factors to regulate gene expression, including 
EMT genes [42]. Mutations in that $\beta$-catenin that prevent phosphorylation by GSK-3 $\beta$, increasing $\beta$-catenin accumulation in the cytoplasm, are frequent in other cancers, but they are absent or in a very low frequency in CCA [43-45]. However, increments in $\beta$-catenin expression both in cytoplasm and nucleus have been observed in $14.1-82 \%$ of iCCA and $12.6 \%$ of eCCA, indicating a release of $\beta$-catenin from the $E$-cadherin/ $\beta$-catenin membranous complex by other mechanisms. These changes were associated with high-grade tumor, tumor size, lymph node metastasis and OS, but not with DFS [20, 21, 24, 31, 32, 44-47].

\section{Intermediate filaments}

Cytokeratin 19 (CK19) and vimentin are members of the intermediate filament family that display a differential cell type expression. While CK19 is expressed in epithelial cells, vimentin is detected in mesenchymal cells. CK19 down-regulation has been observed in tumor cells of CCA, and this down-regulation was significantly associated with neural invasion, intrahepatic metastasis, undifferentiated tumor grade and shortened DFS and OS [24]. Several studies confirmed an aberrant staining of vimentin in CCA tumor cells while there was no staining in benign cholangiocytes [24, 25, 32, 35, 40, 48-50]. Vimentin expression was associated with lymph node metastasis, portal vein invasion, tumor size, pTNM stage and poorer OS and DFS $[25,31,32,35,50]$. In addition, vimentin was mostly detected in poorly differentiated tumor foci and a multivariate analysis demonstrated that aberrant vimentin expression is an independent adverse prognostic factor in iCCA [50]. As expected, vimentin expression was negatively correlated with the expression of CK19 and Ecadherin in iCCA $[24,25,35]$. Consistently, in eCCA cases (both pCCA and dCCA) expressing SNAIL, CK19 expression was lower and vimentin prevailed [48].

\section{S100 Calcium Binding Protein A4 (S100A4)}

S100A4 expression has been associated with transcriptional regulation of MMPs and Ecadherin genes through unidentified mechanisms [51, 52]. Undetectable in normal cholangiocytes, S100A4 immunoreactivity was evidenced in approximately $30-50 \%$ of iCCA $[24,53]$ and $11 \%$ of eCCA [40]. In iCCA, S100A4 protein expression was correlated with 
aggressive clinical parameters, shortened DFS and OS and was an independent prognostic factor in a multivariate analysis [24, 53]. In eCCA, univariate and multivariate analyses revealed that S100A4 was a significant and an independent prognostic factor [40]. Recently, Fabris et al. demonstrated that nuclear S100A4 localization in iCCA and eCCA defines a subclass of CCA associated with decreased OS after resection [54].

\section{EMT-inducing transcription factors (EMT-TFs)}

SNAIL family (SNAIL/SNAI1 and SLUG/SNAI2) is by far the most studied in CCA. Tumor cells from human iCCA expressing both the mesenchymal marker SNAIL in the nucleus and the biliary epithelial marker CK19 were identified by double immunofluorescence staining, providing conclusive evidence for the presence of EMT traits in malignant cholangiocytes [55]. While not detected in normal biliary epithelium, SNAIL mRNA and protein levels are markedly expressed in CCA, with a sub-cellular localization of the protein in the nuclei of iCCA and eCCA tumor cells [24, 32, 37, 39, 48, 56]. High expression of SNAIL transcripts was correlated with the presence of metastasis [56]. Nuclear overexpression of SNAIL protein was associated with aggressive parameters and poor prognosis in both iCCA (28.6$48.6 \%$ of cases) and eCCA (38-54\% of cases), and predicted worse OS and DFS [24, 32, 39, 48]. Consistently with its repressing function on E-cadherin, increased SNAIL mRNA levels were negatively associated with E-cadherin transcripts and protein expression [32, 56]. SLUG is not detected in normal intrahepatic bile ducts and liver parenchyma but is expressed in $72.2 \%$ of iCCA, in which it has been associated with lymphovascular invasion, lymph node and distant metastasis [57]. Furthermore, high expression of SLUG was observed in $38.1 \%$ and $61.9 \%$ of long-term survivors and short-term survivors (short survival time $<12$ months), respectively [57]. Described as an independent indicator of poor prognosis, SLUG could be used as a marker for predicting the outcome of patients with iCCA after surgical resection. High levels of SLUG mRNA were detected in cases of eCCA that displayed nodal and distant metastasis, portal vein and liver artery invasion, and lymphatic and perineural invasion [37], and also correlated with reduced E-cadherin expression. 
TWIST family (TWIST1/TWIST1 and TWIST2/TWIST2). TWIST is overexpressed in CCA tumors and significantly associated with poor prognosis [41]. Moreover, TWIST nuclear expression was significantly correlated with high $\mathrm{N}$-cadherin expression [41]. More particularly, TWIST1 was highly expressed in poorly differentiated and sarcomatous CCA tissues suggesting a close relationship between EMT-TFs and the appearance of a mesenchymal phenotype [58].

ZEB family (ZEB1/ZEB1 and ZEB2/ZEB2). Nuclear ZEB1 was highly expressed in malignant iCCA cells compared to normal non-neoplastic epithelial cells and was associated with aggressive parameters and poorer OS [35, 59]. High expression of ZEB2 was found in $51 \%$ of CCA and correlated with metastasis and poor prognosis [60].

\section{Prognostic value of EMT markers in cholangiocarcinoma}

As summarized above (Table 1), hallmarks of EMT (i.e. disruption of intercellular junctions) as well as expression of the master regulators (EMT-TFs) can be detected in human CCA samples and their presence is associated with poor clinical outcome, both in iCCA and eCCA. However, it should be stressed that if a single marker does not show any correlation with clinicopathological factors and/or patient outcome, the combination of several EMT markers (E-cadherin or $\beta$-catenin, two epithelial markers, with vimentin or fibronectin, two mesenchymal markers) could do, as it has been shown in different tumor types, including CCA [24, 31, 61-63]. Thus, consideration of cumulative alterations of EMT-related markers should be taken into account instead of considering either epithelial or mesenchymal markers individually to predict poor outcomes in human CCA patients. Whether EMT is responsible for the poor outcome of the patients or if EMT markers could be used as

biomarkers of poor outcome needs further investigations with larger cohorts to deepen the current knowledge and strengthen the existing data.

\section{Functional regulatory networks of EMT in cholangiocarcinoma (Table 2)}

\section{Cytokines (Figure 2A)}


Transforming-growth factor- $\beta$ (TGF- $\beta$ )-dependent signaling is the prototypic inducer of EMT in several cancers including CCA [64]. TGF- $\beta 1-3$ and their receptors TGF- $\beta$ RI and RII were found expressed in both CCA tumor cells and surrounding stroma cells [65-70] while no data on TGF- $\beta$ RIII expression is available. Regarding TGF- $\beta 1$, it is expressed not only by invading malignant cholangiocytes, but also by stroma cells (e.g. fibroblasts, hematopoietic cells and macrophages) [71, 72]. Moreover, TGF- $\beta 1$ expression was significantly correlated with lymph node metastasis, distant metastasis, and tumor recurrence in iCCA [73] and shorter OS both in ICCA and eCCA $[69,73]$. Upon TGF- $\beta 1$ stimulation, the expression of epithelial markers decreased concomitantly with an increased expression of mesenchymal markers in CCA cells $[18,41,48,69,74-76]$. Abrogation of TGF- $\beta$-dependent signaling pathway by a soluble TGF- $\beta$ RII reduced CCA cell invasiveness in a murine CCA xenograft model [48]. Similar results were obtained in a rat model of CCA induced by thioacetamide wherein TGF- $\beta$ signaling inhibition by a neutralizing TGF- $\beta$ antibody led to a reduction in number and size of neoplastic ductules [77]. siRNA knockdown of HMGB1 (high-mobility group box 1), a chromatin protein, inhibited TGF- $\beta$-induced EMT in CCA cells, suggesting a role of HMGB1 in TGF- $\beta$ regulation of EMT [78]. Similarly, chloroquine, an autophagy inhibitor, has been described to interfere with EMT induction through TGF- $\beta$ [79], suggesting a potential link between EMT regulation and autophagy. In contrast, another member of the TGF- $\beta$ superfamily, BMP-7 (Bone morphogenetic protein 7), precludes the action of TGF- $\beta$ by promoting the conversion of mesenchymal to epithelial cells [80]. Addition of BMP-7 to CCA cells led to an inhibition of TGF- $\beta 1$-induced EMT by decreasing nuclear expression of TWIST and cell migratory ability [41].

Tumor necrosis factor- $\alpha(T N F-\alpha)$ reduced the expression of epithelial makers (E-cadherin and CK19) and enhanced the expression of mesenchymal markers (S100A4, SNAIL and ZEB2) favoring CCA cell migration in vitro $[56,60]$. In addition, TNF- $\alpha$ was able to induce the expression of MMP9, largely related with tumor invasiveness in CCA [81, 82]. 
Interleukin-6 (IL-6). Patients with CCA display high levels of IL-6 in serum and in malignant cholangiocytes [83, 84]. Interestingly, IL-6 is not only expressed by malignant cholangiocytes, but also by surrounding cells (e.g. fibroblasts, hematopoietic cells and macrophages) in human CCA tumors [71, 72]. IL-6 triggers EMT in CCA cells by promoting membrane E-cadherin down-regulation, cell scattering and up-regulation of mesenchymal markers $\mathrm{N}$-cadherin and vimentin [71, 85]. The suppressor of cytokine signaling 3 (SOCS3), which regulates IL-6/STAT3 pathway by antagonizing STAT3 tyrosine phosphorylation, inhibits IL-6-induced EMT [85]. Furthermore, a crosstalk between IL-6 and TGF- $\beta 1$ in EMT has been emphasized in CCA [71]. Both factors induce endogenous expression of IL-6 and TGF- $\beta 1$ in CCA cells through Smad4. Thus, inhibition of Smad4 halted the IL-6/TGF- $\beta 1$ crosstalk loop, and reversed IL-6/TGF- $\beta 1$-induced EMT. In human samples, all protagonists, IL-6, TGF- $\beta 1$, Smad4 along with the mesenchymal marker N-cadherin are expressed at the invasion front of tumor cells, suggesting that Smad4 may represent a therapeutic target not only to halt CCA progression, but also to control pro-inflammatory environment maintenance [71].

\section{Receptor tyrosine kinases (Figure 2B)}

Epidermal Growth Factor Receptor (EGFR) expression and signaling are strongly associated with CCA development and progression [70, 86-88]. We recently showed that ectopic cytoplasmic localization of E-cadherin is correlated with EGFR overexpression in human iCCA and PCCA [29]. Interestingly, E-cadherin also displayed a cytoplasmic pattern in xenografted tumors, whereas the mice treatment with gefitinib restored the membranous expression of E-cadherin. In vitro, EGF and HB-EGF, two EGFR ligands, induced scattering of CCA cells that resulted from the disruption of adherens junctions [29, 68]. In EGFstimulated CCA cells, EMT-TFs (SLUG and ZEB1) and mesenchymal markers (N-cadherin and $\alpha-S M A)$ were induced, favoring cell invasiveness through cytoskeleton remodeling [29, 89]. We obtained similar results after down-regulating the PDZ scaffold protein EBP50 which led to the implementation of an EMT program through EGFR activation with the subsequent 
acquisition of invasive and migratory properties by CCA cells [86]. Besides EBP50, SOX4 transcription factor has been described as a potent inducer of EMT in CCA cells possibly through modulation of EGFR expression [90].

Eph Receptors and their ligands are expressed at very low levels in normal cholangiocytes [91, 92]. Among Eph receptors, EphA2 and EphB2 were increased in CCA tumors and correlated with the metastatic status of patients and poorer tumor differentiation [91, 92]. Overexpression of EphA2 in CCA cells induced a down-regulation of cell-cell junction proteins and an up-regulation of mesenchymal markers, leading to the acquisition of fibroblastic appearance and invasive properties.

\section{G protein-coupled receptors (Figure 2C)}

H4 Histamine receptor $(H 4 H R)$. While $\mathrm{H} 1 \mathrm{HR}$ and $\mathrm{H} 2 \mathrm{HR}$ stimulate biliary hyperplasia and CCA growth, H3HR and H4HR decrease CCA progression [93]. H4HR is up-regulated in human CCA cells compared to non-malignant tissue [94]. CCA cells treated with the specific

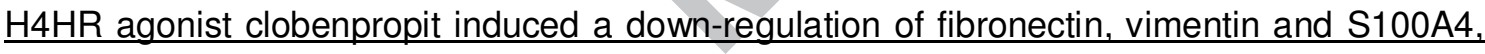
while expression of epithelial markers CK7, CK8 and CK19 was maintained. Consequently, clobenpropit treatment reduced invasive and metastatic potential of CCA cells [94].

C-X-C-motif Chemokine Receptor-4 (CXCR4) binds the stromal-derived-factor-1 (SDF-1; also called CXCL12). CXCR4 is expressed by tumor cells in human CCA but not in the adjacent non-tumor tissue $[95,96]$. High expression of CXCR4 is associated with metastasis and poor clinical outcome of iCCA. In vitro, CXCR4 acts as a potent activator of EMT by increasing expression of SLUG, vimentin and MMP-9, promoting cell migration and invasion through a $\beta$-catenin-dependent mechanism [96].

\section{Development-related pathways (Figure 2D)}

Notch signaling. Notch-1 and Notch-4 expression is up-regulated in tumor cells from iCCA compared with adjacent non-tumor liver tissues [97-100]. In eCCA, the four Notch receptors were overexpressed [101] and high expression of Notch-1 and Notch-3 was related to advanced TNM stage and advanced T stage, respectively, suggesting a contribution of both 
receptors to eCCA progression. After stimulation, Notch is cleaved by a $\mathrm{Y}$-secretase and the Notch intracellular domain is released and translocated into the nucleus to activate target gene transcription. As in many other cancers, Notch signaling activation led to EMT induction in CCA cells. Notch-1 overexpression causes an increase in $\alpha-S M A$ and vimentin expression and a decrease in E-cadherin protein levels. All these events were accompanied by a cellular morphological change and cytoskeleton reorganization characteristic of EMT activation [98]. Consistently, Notch-1 inhibition by a $\mathrm{Y}$-secretase inhibitor decreased vimentin and SNAIL expression, as well as impaired invasion and migration in CCA cells [102]. Among Notch signaling target genes, Sox9 plays a fundamental role in biliary pathophysiology [103, 104]. Sox9 has been recently linked to the activation of EMT in CCA [105]. Since Sox9 has been described as a Notch1 mediator in EMT activation in lung adenocarcinoma [106], it could play a similar role in CCA.

Hedgehog signaling. Upon Hedgehog ligand binding, GPCR-like protein Smoothened is released by Patched receptor and allows generating activated GLI1-3. Hedgehog signaling components are overexpressed in iCCA [107-109], and it has been shown that GLI1 and GLI2 overexpression was associated with intrahepatic metastasis and poorer OS and DFS [108]. A role of Hedgehog signaling in EMT has been described in human CCA cells and CCA xenografted tumors by modulating E-cadherin expression [107] Consistently, inhibition of Hedgehog signaling by cyclopamine [107] or capsaicin [110] up-regulated E-cadherin expression [107] and impaired EMT in CCA [110].

\section{microRNAs (miRs) (Figure 2E)}

miRs are deeply involved in EMT regulation [14]. So far, 6 miRs including miR-221 [111], mir200c [112], miR-204 [113] miR-214 [114], miR-34a [76] and miR-21 [115] have been described to regulate EMT in CCA. With the exception of miR-221 and miR-21, which are upregulated in CCA tissue and associated with poor survival, all the others are down-regulated in human CCA. 
Transcriptomic profiling of iCCA tissues revealed that a signalling pathway linking miR-200c to EMT is preferentially activated in iCCA that display stem cell gene expression traits [112]. Ingenuity Pathway Analysis showed that miR-200c was negatively correlated with genes from the TGF- $\beta$ signalling pathway, and NCAM1 (Neural Cell Adhesion Molecule 1) was experimentally demonstrated to be a direct target of miR-200c. Forced expression of miR$\underline{200 \mathrm{c} \text { in } \mathrm{HuH} 28 \text {, a CCA cell line that displays a fibroblastic-like cell morphology and low levels }}$ of miR-200c, led to an inhibition of EMT with suppression of mesenchymal gene expression (ZEB1/2, vimentin and N-cadherin) and increment of E-cadherin. Conversely, miR-200C down-regulation in HuCC-T1, a CCA cell line with epithelial appearances and high expression of miR-200c, led to an activation of EMT with an induction of mesenchymal markers and a repression of E-cadherin [112].

miR-204, miR-214 and miR-34a inhibit EMT in CCA by targeting SLUG, TWIST and Smad4, respectively $[76,113,114]$, while $\mathrm{miR}-221$ and miR-21 positively regulate EMT by directly repressing PTEN and by unidentified mechanisms, respectively $[111,115]$.

\section{Additional regulatory factors}

Unconjugated primary bile acid, chenodeoxycholic acid, and the secondary bile acid, lithocholic acid, induce SNAIL expression and E-cadherin down-regulation in CCA cells, at least in part, through two transcription factors, Nuclear factor-Y and Stimulating protein 1 [116]. Whether these effects involve the bile acid receptors, Farnesoid X Receptor and G protein-coupled bile acid receptor 1 (TGR5), remains to be elucidated. However, since bile acids can activate EGFR [117], they may induce indirectly EMT through EGFR signaling pathway.

Hepatitis $C$ virus core (HCVC) in CCA tissues was associated with decreased E-cadherin expression and increased $\mathrm{N}$-cadherin, vimentin and fibronectin expression [118, 119]. A correlation between HCVc and metastasis in lymph nodes and other organs was evidenced. Consistently, expression of HCVc in CCA cells induced a fibroblastic and scattered appearance, along with an augmentation of vimentin and fibronectin, and a down-regulation 
of E-cadherin, that may be mediated by lysyl oxidase homolog $2[118,119]$. These effects may be of special relevance in areas of East-Asia with high HCV prevalence or countries where the diagnosis of primary tumors in livers with a cirrhotic background has been recently increasing [2].

Small proline rich protein 2a (SPRR2a) overexpression in CCA cells induced EMT, which in turn promotes invasiveness $[59,120]$. Further experiments showed that SPRR2A acts as a transcriptional corepressor with ZEB1 to repress miR-200c/141 transcription in CCA cells in order to maintain a mesenchymal phenotype [59].

In addition, 14-3-3zeta and aPKC-ı [121, 122], adrenomedullin [123], Forkhead box protein C2 [124],-WAVE3 [125] and Fibroblast growth factor (FGF)19/FGFR4 axis [126] promote EMT in CCA. Conversely, FBXW7 [127, 128], thymosin $\beta 10$ [129] and MAP3K4 [130] act as negative regulators of EMT through inhibition of mTOR, ERK1/2 and NFKB pathways, respectively.

\section{EMT regulation by the microenvironment in cholangiocarcinoma}

For a long time perceived as a tissue composed only of cancer cells, the tumor tissue is in fact, like all tissues, composed of different cellular and acellular components. It is now well established that all these components constitute a favorable environment for tumor development. CCA is characterized by a prominent desmoplastic stroma [3], which is composed primarily by cancer-associated fibroblasts (CAFs) and to a lesser proportion of tumor-associated macrophages (TAM) and vascular cells. As discussed below, stromal cells play a key role in CCA progression through reciprocal interactions with malignant cells that lead to EMT activation.

\section{Cancer-associated fibroblasts (CAFs) and hepatic stellate cells (HSCs) (Figure 3A)}

CAFs are probably derived from activated HSCs and/or portal (or periductal) fibroblasts in the liver [131] although a circulating bone-marrow-derived precursor cell origin has also been suggested. The possibility that cholangiocytes could also feed the pool of stroma myofibroblasts has been refuted in different models of fibrosis [132] and more recently in a 
murine model of xenografted tumors [133]. CAFs have a crucial role in favoring CCA progression, and more particularly in promoting EMT, through interactive autocrine and paracrine signaling pathways $[68,131]$. We have recently shown that CAFs from human iCCA synthesize HB-EGF, which activates EGFR in CCA cells leading to the disruption of cell-cell junctions and an increase of invasiveness [68]. Furthermore, we described a paracrine reciprocal loop in which CCA cells produced TGF- $\beta 1$ that stimulates HB-EGF expression by CAF. Thus, this cyclic interplay between tumor and stroma cells, contributes to EMT of CCA cells through a constant activation of EGFR pathway.

Regarding the intercellular dialogue between HSCs and CCA cells, the SDF-1/CXCR4 axis has been described as a major interaction pathway, which could contribute to stromal fibrosis in CCA $[75,95]$. It has been shown that SDF-1 and CXCR4 are expressed by HSCs in human iCCA. In vitro, angiotensin II and TGF- $\beta$ enhanced the release of SDF-1 by LI-90 cells (a human HSC line), which in turn, promoted activation of LI-90 cells. Furthermore, SDF-1 reduced E-cadherin expression and enhanced nuclear $\beta$-catenin and vimentin expression in CXCR4-expressing CCA cells [75]. In this study, angiotensin II was shown to act not only on HSCs, but also on CCA tumor cells by inducing EMT.

\section{Tumor-associated macrophages (TAMs) and mast cells (Figure 3B)}

TAMs represent the major class of immune cells within the tumor microenvironment and derive from circulating monocytes that infiltrate tumor tissues and differentiate into macrophages. Many infiltrating CD68-positive macrophages and TNF-a-positive macrophages exist at the iCCA interface [134, 135]. TAMs secrete several factors that influence EMT in CCA tumor cells. CCA cells cultured in presence of conditioned media from activated TAMs experienced an accumulation of $\beta$-catenin in cell cytoplasm [46] downregulation of E-cadherin and $\mathrm{CK} 19$, and an increment in the expression of mesenchymal markers (i.e. S100A4, N-cadherin and MMP9) [72, 136], as well as an increment in cell migration. This augmented migration could explain the association between the extrahepatic metastases and the high density of TAMs described in patients with CCA [136]. The 
paracrine stimulation of EMT in CCA tumor cells by TAMs may be related to the production and secretion of interleukins, TNF- $\alpha$ and TGF- $\beta 1$ by activated macrophages [72]. More recently, TAMs have been described as potent providers of Wnt ligands [137], which are known to induce EMT in other cancers $[138,139]$.

Mast cells are master regulators of the immune system, which are involved in liver pathogenesis [140]. Inhibition of mast cell-derived histamine prevents EMT switch and ECM breakdown in CCA cells through $\mathrm{H} 1 \mathrm{HR}$ and H2HR [141]. Moreover, if the SCF/Kit pathway involved in tumor mast cell recruitment is inhibited, the paracrine influence of mast cells on CCA is vanished [141], suggesting a role of mast cells/tumor cells interaction in the promotion of EMT and progression of CCA.

The information summarized above points out the role of the different cell types within the tumor, and not only cancer cells, in CCA progression, and more specifically in the activation of EMT that may lead to metastasis. Although not related to EMT, a recent study [142] showed the possibility of targeting CAFs in a syngeneic rat model with a pro-apoptotic drug called Navitoclax, which suppressed tumor growth and improved host survival. Therefore, efforts should be directed to the development of targeted therapies against both tumor cells and their interactions with the surrounding stroma, in order to reduce metastasis and improve patient conditions.

\section{EMT and therapeutic considerations}

\section{Chemoresistance}

Drug resistance is a challenge constantly faced by clinicians regarding the use of antitumor agents in patients. In CCA, EMT has been identified in vitro as a mechanism of resistance against gemcitabine and cisplatin $[71,143]$, both used in combination as the standard of care for patients with CCA [9]. Yamada et al., recently showed that CCA cell lines exhibiting mesenchymal traits were more resistant to gemcitabine than CCA cell lines having a prominent epithelial phenotype [71]. IL-6 and TGF- $\beta 1$, through an autocrine and crosstalk loop involving Smad4, were incriminated in the resistance to gemcitabine by inducing EMT. 
Indeed, establishment of gemcitabine-resistant CCA cell lines showed that these cells displayed a reduced expression of $\mathrm{E}$-cadherin and an increased expression of $\mathrm{N}$-cadherin and vimentin [71]. In addition, inhibition of SLUG sensitized CCA cells to cisplatin through upregulation of the proapoptotic protein PUMA [143]. It is noteworthy that the activity of EMTTFs is not restricted to the repression of E-cadherin promoter, but they also trigger cell survival by promoting apoptosis escape of tumor cells through inhibition of PUMA-mediated cell death in CCA $[15,144]$.

Something that is worth to be mentioned is the increasing evidence suggesting that EMT could be associated with other features such as the acquisition of cancer stem cell (CSC) properties [145]. The acquisition of CSC properties by tumor mesenchymal-like cells in response to EMT could have major consequences, in particular by fostering tumor heterogeneity and by contributing to resistance to anticancer drugs in CCA, a tumor containing a strong contingent of CSC [55]. In fact, Shuang et al. have recently found, both in iCCA and eCCA, a significant correlation between TGF- $\beta 1$ and ALDH1 (aldehyde dehydrogenase 1), a functional CSC marker. In addition, TGF- $\beta 1$-induced EMT in CCA cells resulted in an acquisition of mesenchymal traits, as well as ALDH expression, which were accompanied by a decreased sensitivity to 5-fluorouracil [69].

By helping cells to counteract endogenous safeguard mechanisms, EMT may confer resistance to cell death triggered by chemotherapeutic agents. However, it still remains unclear whether chemotherapeutic agents directly induce EMT or lead to the selection of tumor cells that already display EMT traits.

\section{Targeting EMT pathways}

The first thought when it comes to target EMT would be playing with E-cadherin repressors. However, the master EMT regulators are transcription factors, what make them quite difficult to target. Thus, the most useful alternative strategy would be the use of drugs that negatively regulate EMT, though only few studies testing chemical agents against EMT in CCA have been performed. Paclitaxel is a chemotherapeutic agent that stabilizes microtubules and 
arrests cell cycle. At low doses, paclitaxel has been shown to inhibit TGF- $\beta$-induced EMT in CCA cells [74]. FTY720, a synthetic sphingosine immunosuppressant, inhibits EMT and favors reversion of EMT that is called MET (mesenchymal-epithelial transition) in CCA cells and, prevents metastasis in vivo after implantation of CCA cells into the peritoneal cavity of immunocompromised mice [146]. Recently, taking advantage of the presence of CXCR4 at the surface of CCA cells, a polymeric CXCR4 antagonist capable of delivering miR-200c has been developed to inhibit EMT inducer ZEB1 in CCA cells [147]. miR-200c was chosen as a potential treatment for its ability to target ZEB1. Thus the combination CXCR4 antagonist/miR200c offers a promising antimetastatic strategy for the CCA treament, which must be tested in preclinical models to move forward. In addition, as displayed above, EMT is highly regulated by a large number of signaling pathways. These pathways are targetable by drugs currently tested in preclinical studies or clinical trials in CCA, such as the EGFR inhibitor erlotinib (see reviews [13, 148]).

However, in many cases the prolonged use of these drugs results in the opposite undesired effect, the induction of an EMT program as a chemoresistance mechanism through the activation of compensatory alternative pathways. This issue has already been described in $\underline{\text { non-small cell lung cancer, where src/FAK signaling pathway was up-regulated in a resistant }}$ cell line to erlotinib leading to EMT [149]. Furthermore, our preliminary results suggest that EMT is induced as a mechanism involved in acquired resistance to erlotinib in human CCA cells, probably through an up-regulation of IGF signaling [150].

\section{Final remarks and future perspectives}

Given the large body of evidence displayed in this review, there is no doubt of the prominent role of EMT in CCA progression. It becomes imperative to consider EMT as another player in the high metastatic and chemoresistant features characteristic of this tumor. However, some points should be taken in consideration before jumping to patient treatment. Definition of proper combinations of epithelial and mesenchymal markers is eagerly needed in order to select the appropriate patients for the available therapies and the prediction of possible 
outcomes. Among these markers, proper characterization of EMT-TFs is of special importance, since they are deeply involved in the induction of the highly chemoresistant CSC phenotype that has not been profoundly investigated in CCA. Furthermore, since CCA is a very complex and heterogeneous tumor with a prominent stromal component that interacts closely with cancer cells, strong effort should be directed to the development of combinational therapies directed towards both cancer and stromal cells. Finally, the possibility to inhibit signaling pathways involved in this complex process with single molecules against receptors or intracellular kinases should be taken with extreme care, given that the inhibition of these pathways could also trigger compensatory pathways leading to EMT induction as a mechanism of resistance.

Altogether, EMT has become an attractive therapeutic target for CCA. However, due to the redundancies and bypasses among the different signaling pathways and cell types involved, further studies focused on the development of combination therapeutics targeting EMT in CCA are eagerly needed. 


\section{References}

[1] Global Burden of Disease Cancer C, Fitzmaurice C, Dicker D, Pain A, Hamavid H, Moradi-Lakeh M, et al. The Global Burden of Cancer 2013. JAMA oncology 2015;1:505-527.

[2] Banales JM, Cardinale V, Carpino G, Marzioni M, Andersen JB, Invernizzi P, et al. Expert consensus document: Cholangiocarcinoma: current knowledge and future perspectives consensus statement from the European Network for the Study of Cholangiocarcinoma (ENS-CCA). Nature reviews Gastroenterology \& hepatology 2016;13:261-280.

[3] Sirica AE, Gores GJ. Desmoplastic stroma and cholangiocarcinoma: clinical implications and therapeutic targeting. Hepatology 2014;59:2397-2402.

[4] Blechacz B, Komuta M, Roskams T, Gores GJ. Clinical diagnosis and staging of cholangiocarcinoma. Nature reviews Gastroenterology \& hepatology 2011;8:512-522.

[5] Patel T. Increasing incidence and mortality of primary intrahepatic cholangiocarcinoma in the United States. Hepatology 2001;33:1353-1357.

[6] Pichlmayr R, Weimann A, Klempnauer J, Oldhafer KJ, Maschek H, Tusch G, et al. Surgical treatment in proximal bile duct cancer. A single-center experience. Annals of surgery 1996;224:628-638.

[7] Klempnauer J, Ridder GJ, Werner M, Weimann A, Pichlmayr R. What constitutes long-term survival after surgery for hilar cholangiocarcinoma? Cancer 1997;79:26-34.

[8] Zhu AX. Future directions in the treatment of cholangiocarcinoma. Best practice \& research Clinical gastroenterology 2015;29:355-361.

[9] Valle J, Wasan H, Palmer DH, Cunningham D, Anthoney A, Maraveyas A, et al. Cisplatin plus gemcitabine versus gemcitabine for biliary tract cancer. The New England journal of medicine 2010;362:1273-1281.

[10] Nieto MA, Cano A. The epithelial-mesenchymal transition under control: global programs to regulate epithelial plasticity. Seminars in cancer biology 2012;22:361-368.

[11] Guarino M, Rubino B, Ballabio G. The role of epithelial-mesenchymal transition in cancer pathology. Pathology 2007;39:305-318. 
[12] De Wever O, Pauwels P, De Craene B, Sabbah M, Emami S, Redeuilh G, et al. Molecular and pathological signatures of epithelial-mesenchymal transitions at the cancer invasion front. Histochemistry and cell biology 2008;130:481-494.

[13] Thiery JP, Acloque H, Huang RY, Nieto MA. Epithelial-mesenchymal transitions in development and disease. Cell 2009;139:871-890.

[14] Lamouille S, Subramanyam D, Blelloch R, Derynck R. Regulation of epithelialmesenchymal and mesenchymal-epithelial transitions by microRNAs. Current opinion in cell biology 2013;25:200-207.

[15] Puisieux A, Brabletz T, Caramel J. Oncogenic roles of EMT-inducing transcription factors. Nature cell biology 2014;16:488-494.

[16] Moyret-Lalle C, Ruiz E, Puisieux A. Epithelial-mesenchymal transition transcription factors and miRNAs: "Plastic surgeons" of breast cancer. World journal of clinical oncology 2014;5:311-322.

[17] Gumbiner BM. Regulation of cadherin-mediated adhesion in morphogenesis. Nature reviews Molecular cell biology 2005;6:622-634.

[18] Araki K, Shimura T, Suzuki H, Tsutsumi S, Wada W, Yajima T, et al. E/N-cadherin switch mediates cancer progression via TGF-beta-induced epithelial-to-mesenchymal transition in extrahepatic cholangiocarcinoma. British journal of cancer 2011;105:1885-1893.

[19] Li Q, Wang JM, Liu C, Xiao BL, Lu JX, Zou SQ. Correlation of aPKC-iota and Ecadherin expression with invasion and prognosis of cholangiocarcinoma. Hepatobiliary \& pancreatic diseases international : HBPD INT 2008;7:70-75.

[20] Ashida K, Terada T, Kitamura Y, Kaibara N. Expression of E-cadherin, alpha-catenin, beta-catenin, and CD44 (standard and variant isoforms) in human cholangiocarcinoma: an immunohistochemical study. Hepatology 1998;27:974-982.

[21] Settakorn J, Kaewpila N, Burns GF, Leong AS. FAT, E-cadherin, beta catenin, HER 2/neu, Ki67 immuno-expression, and histological grade in intrahepatic cholangiocarcinoma. Journal of clinical pathology 2005;58:1249-1254. 
[22] Farazi PA, Zeisberg M, Glickman J, Zhang Y, Kalluri R, DePinho RA. Chronic bile duct injury associated with fibrotic matrix microenvironment provokes cholangiocarcinoma in p53-deficient mice. Cancer research 2006;66:6622-6627.

[23] Nemeth Z, Szasz AM, Somoracz A, Tatrai P, Nemeth J, Gyorffy H, et al. Zonula occludens-1, occludin, and E-cadherin protein expression in biliary tract cancers. Pathology oncology research : POR 2009;15:533-539.

[24] Ryu HS, Chung JH, Lee K, Shin E, Jing J, Choe G, et al. Overexpression of epithelialmesenchymal transition-related markers according to cell dedifferentiation: clinical implications as an independent predictor of poor prognosis in cholangiocarcinoma. Human pathology 2012;43:2360-2370.

[25] Yao X, Wang X, Wang Z, Dai L, Zhang G, Yan Q, et al. Clinicopathological and prognostic significance of epithelial mesenchymal transition-related protein expression in intrahepatic cholangiocarcinoma. OncoTargets and therapy 2012;5:255-261.

[26] Gu MJ, Choi JH. Clinicopathological significance of E-cadherin, beta-catenin and epidermal growth factor receptor expression in intrahepatic cholangiocarcinoma. Hepatogastroenterology 2012;59:1241-1244.

[27] Mao X, Chen D, Wu J, Li J, Zhou H, Wu Y, et al. Differential expression of fascin, Ecadherin and vimentin: Proteins associated with survival of cholangiocarcinoma patients. The American journal of the medical sciences 2013;346:261-268.

[28] Techasen A, Loilome W, Namwat N, Khuntikeo N, Puapairoj A, Jearanaikoon P, et al. Loss of E-cadherin promotes migration and invasion of cholangiocarcinoma cells and serves as a potential marker of metastasis. Tumour biology : the journal of the International Society for Oncodevelopmental Biology and Medicine 2014;35:8645-8652.

[29] Claperon A, Mergey M, Nguyen Ho-Bouldoires TH, Vignjevic D, Wendum D, Chretien $\mathrm{Y}$, et al. EGF/EGFR axis contributes to the progression of cholangiocarcinoma through the induction of an epithelial-mesenchymal transition. Journal of hepatology 2014;61:325-332.

[30] Endo K, Ashida K, Miyake N, Terada T. E-cadherin gene mutations in human intrahepatic cholangiocarcinoma. The Journal of pathology 2001;193:310-317. 
[31] Gu MJ, Choi JH. Epithelial-mesenchymal transition phenotypes are associated with patient survival in intrahepatic cholangiocarcinoma. Journal of clinical pathology 2014;67:229-234.

[32] Huang XY, Zhang C, Cai JB, Shi GM, Ke AW, Dong ZR, et al. Comprehensive multiple molecular profile of epithelial mesenchymal transition in intrahepatic cholangiocarcinoma patients. PloS one 2014;9:e96860.

[33] Lee S, Kim WH, Jung HY, Yang MH, Kang GH. Aberrant CpG island methylation of multiple genes in intrahepatic cholangiocarcinoma. The American journal of pathology 2002;161:1015-1022.

[34] Mosnier JF, Kandel C, Cazals-Hatem D, Bou-Hanna C, Gournay J, Jarry A, et al. Ncadherin serves as diagnostic biomarker in intrahepatic and perihilar cholangiocarcinomas. Modern pathology : an official journal of the United States and Canadian Academy of Pathology, Inc 2009;22:182-190.

[35] Terashita K, Chuma M, Hatanaka Y, Hatanaka K, Mitsuhashi T, Yokoo H, et al. ZEB1 expression is associated with prognosis of intrahepatic cholangiocarcinoma. Journal of clinical pathology 2015.

[36] Zhai B, Yan HX, Liu SQ, Chen L, Wu MC, Wang HY. Reduced expression of P120 catenin in cholangiocarcinoma correlated with tumor clinicopathologic parameters. World journal of gastroenterology : WJG 2008;14:3739-3744.

[37] Zhang KJ, Wang DS, Zhang SY, Jiao XL, Li CW, Wang XS, et al. The E-cadherin repressor slug and progression of human extrahepatic hilar cholangiocarcinoma. Journal of experimental \& clinical cancer research : CR 2010;29:88.

[38] Yang B, House MG, Guo M, Herman JG, Clark DP. Promoter methylation profiles of tumor suppressor genes in intrahepatic and extrahepatic cholangiocarcinoma. Modern pathology : an official journal of the United States and Canadian Academy of Pathology, Inc 2005;18:412-420.

[39] Kong D, Liang J, Li R, Liu S, Wang J, Zhang K, et al. Prognostic significance of snail expression in hilar cholangiocarcinoma. Brazilian journal of medical and biological research = 
Revista brasileira de pesquisas medicas e biologicas / Sociedade Brasileira de Biofisica [et al] 2012;45:617-624.

[40] Nitta T, Mitsuhashi T, Hatanaka Y, Miyamoto M, Oba K, Tsuchikawa T, et al. Prognostic significance of epithelial-mesenchymal transition-related markers in extrahepatic cholangiocarcinoma: comprehensive immunohistochemical study using a tissue microarray. British journal of cancer 2014;111:1363-1372.

[41] Duangkumpha K, Techasen A, Loilome W, Namwat N, Thanan R, Khuntikeo N, et al. BMP-7 blocks the effects of TGF-beta-induced EMT in cholangiocarcinoma. Tumour biology : the journal of the International Society for Oncodevelopmental Biology and Medicine 2014.

[42] Valenta T, Hausmann G, Basler K. The many faces and functions of beta-catenin. The EMBO journal 2012;31:2714-2736.

[43] Koch E, Fiedler W, Tannapfel A, Ballhausen WG. Alteration of the fragile histidine triad gene in intrahepatic cholangiocarcinoma. European journal of gastroenterology \& hepatology 2003;15:907-913.

[44] Sugimachi K, Taguchi K, Aishima S, Tanaka S, Shimada M, Kajiyama K, et al. Altered expression of beta-catenin without genetic mutation in intrahepatic cholangiocarcinoma. Modern pathology : an official journal of the United States and Canadian Academy of Pathology, Inc 2001;14:900-905.

[45] Tokumoto N, Ikeda S, Ishizaki Y, Kurihara T, Ozaki S, Iseki M, et al. Immunohistochemical and mutational analyses of Wnt signaling components and target genes in intrahepatic cholangiocarcinomas. International journal of oncology 2005;27:973980.

[46] Loilome W, Bungkanjana P, Techasen A, Namwat N, Yongvanit P, Puapairoj A, et al. Activated macrophages promote Wnt/beta-catenin signaling in cholangiocarcinoma cells. Tumour biology : the journal of the International Society for Oncodevelopmental Biology and Medicine 2014;35:5357-5367. 
[47] Jachin S, Bae JS, Sung JJ, Park HS, Jang KY, Chung MJ, et al. The role of nuclear EpICD in extrahepatic cholangiocarcinoma: association with beta-catenin. International journal of oncology 2014;45:691-698.

[48] Sato Y, Harada K, Itatsu K, Ikeda H, Kakuda Y, Shimomura S, et al. Epithelialmesenchymal transition induced by transforming growth factor-\{beta\}1/Snail activation aggravates invasive growth of cholangiocarcinoma. The American journal of pathology 2010;177:141-152.

[49] Dos Santos A, Court M, Thiers V, Sar S, Guettier C, Samuel D, et al. Identification of cellular targets in human intrahepatic cholangiocarcinoma using laser microdissection and accurate mass and time tag proteomics. Molecular \& cellular proteomics : MCP 2010;9:19912004.

[50] Korita PV, Wakai T, Ajioka Y, Inoue M, Takamura M, Shirai Y, et al. Aberrant expression of vimentin correlates with dedifferentiation and poor prognosis in patients with intrahepatic cholangiocarcinoma. Anticancer research 2010;30:2279-2285.

[51] Boye K, Maelandsmo GM. S100A4 and metastasis: a small actor playing many roles. The American journal of pathology 2010;176:528-535.

[52] Sherbet GV. Metastasis promoter S100A4 is a potentially valuable molecular target for cancer therapy. Cancer letters 2009;280:15-30.

[53] Tian X, Wang Q, Li Y, Hu J, Wu L, Ding Q, et al. The expression of S100A4 protein in human intrahepatic cholangiocarcinoma: clinicopathologic significance and prognostic value. Pathology oncology research : POR 2015;21:195-201.

[54] Fabris L, Cadamuro M, Moserle L, Dziura J, Cong X, Sambado L, et al. Nuclear expression of S100A4 calcium-binding protein increases cholangiocarcinoma invasiveness and metastasization. Hepatology 2011;54:890-899.

[55] Cardinale V, Renzi A, Carpino G, Torrice A, Bragazzi MC, Giuliante F, et al. Profiles of cancer stem cell subpopulations in cholangiocarcinomas. The American journal of pathology 2015;185:1724-1739. 
[56] Techasen A, Namwat N, Loilome W, Bungkanjana P, Khuntikeo N, Puapairoj A, et al. Tumor necrosis factor-alpha (TNF-alpha) stimulates the epithelial-mesenchymal transition regulator Snail in cholangiocarcinoma. Medical oncology 2012;29:3083-3091.

[57] Zhang KJ, Zhang BY, Zhang KP, Tang LM, Liu SS, Zhu DM, et al. Clinicopathologic significance of slug expression in human intrahepatic cholangiocarcinoma. World journal of gastroenterology : WJG 2010;16:2554-2557.

[58] Seol MA, Chu IS, Lee MJ, Yu GR, Cui XD, Cho BH, et al. Genome-wide expression patterns associated with oncogenesis and sarcomatous transdifferentation of cholangiocarcinoma. BMC cancer 2011;11:78.

[59] Mizuguchi Y, Isse K, Specht S, Lunz JG, 3rd, Corbitt N, Takizawa T, et al. Small proline rich protein 2a in benign and malignant liver disease. Hepatology 2014;59:1130-1143. [60] Techasen A, Namwat N, Loilome W, Duangkumpha K, Puapairoj A, Saya H, et al. Tumor necrosis factor-alpha modulates epithelial mesenchymal transition mediators ZEB2 and S100A4 to promote cholangiocarcinoma progression. Journal of hepato-biliarypancreatic sciences $2014 ; 21: 703-711$.

[61] Bae YK, Choi JE, Kang SH, Lee SJ. Epithelial-Mesenchymal Transition Phenotype Is Associated with Clinicopathological Factors That Indicate Aggressive Biological Behavior and Poor Clinical Outcomes in Invasive Breast Cancer. Journal of breast cancer 2015;18:256263.

[62] Kim A, Bae YK, Gu MJ, Kim JY, Jang KY, Bae HI, et al. Epithelial-mesenchymal transition phenotype is associated with patient survival in small intestinal adenocarcinoma. Pathology 2013;45:567-573.

[63] Sung $\mathrm{CO}$, Park $\mathrm{CK}$, Kim SH. Classification of epithelial-mesenchymal transition phenotypes in esophageal squamous cell carcinoma is strongly associated with patient prognosis. Modern pathology : an official journal of the United States and Canadian Academy of Pathology, Inc 2011;24:1060-1068. 
[64] Reichl P, Haider C, Grubinger M, Mikulits W. TGF-beta in epithelial to mesenchymal transition and metastasis of liver carcinoma. Current pharmaceutical design 2012;18:41354147.

[65] Zen Y, Harada K, Sasaki M, Chen TC, Chen MF, Yeh TS, et al. Intrahepatic cholangiocarcinoma escapes from growth inhibitory effect of transforming growth factorbeta1 by overexpression of cyclin D1. Laboratory investigation; a journal of technical methods and pathology 2005;85:572-581.

[66] Benckert C, Jonas S, Cramer T, Von Marschall Z, Schafer G, Peters M, et al. Transforming growth factor beta 1 stimulates vascular endothelial growth factor gene transcription in human cholangiocellular carcinoma cells. Cancer research 2003;63:10831092.

[67] Lee KT, Liu TS. Expression of transforming growth factor betas and their signaling receptors in stone-containing intrahepatic bile ducts and cholangiocarcinoma. World journal of surgery $2003 ; 27: 1143-1148$.

[68] Claperon A, Mergey M, Aoudjehane L, Ho-Bouldoires TH, Wendum D, Prignon A, et al. Hepatic myofibroblasts promote the progression of human cholangiocarcinoma through activation of epidermal growth factor receptor. Hepatology 2013;58:2001-2011.

[69] Shuang ZY, Wu WC, Xu J, Lin G, Liu YC, Lao XM, et al. Transforming growth factorbeta1-induced epithelial-mesenchymal transition generates ALDH-positive cells with stem cell properties in cholangiocarcinoma. Cancer letters 2014;354:320-328.

[70] Andersen JB, Spee B, Blechacz BR, Avital I, Komuta M, Barbour A, et al. Genomic and genetic characterization of cholangiocarcinoma identifies therapeutic targets for tyrosine kinase inhibitors. Gastroenterology 2012;142:1021-1031 e1015.

[71] Yamada D, Kobayashi S, Wada H, Kawamoto K, Marubashi S, Eguchi H, et al. Role of crosstalk between interleukin-6 and transforming growth factor-beta 1 in epithelialmesenchymal transition and chemoresistance in biliary tract cancer. European journal of cancer 2013;49:1725-1740. 
[72] Techasen A, Loilome W, Namwat N, Dokduang H, Jongthawin J, Yongvanit P. Cytokines released from activated human macrophages induce epithelial mesenchymal transition markers of cholangiocarcinoma cells. Asian Pacific journal of cancer prevention : APJCP 2012;13 Suppl:115-118.

[73] Chen Y, Ma L, He Q, Zhang S, Zhang C, Jia W. TGF-beta1 expression is associated with invasion and metastasis of intrahepatic cholangiocarcinoma. Biological research 2015;48:26.

[74] Hirose A, Tajima H, Ohta T, Tsukada T, Okamoto K, Nakanuma S, et al. Low-dose paclitaxel inhibits the induction of epidermal-mesenchymal transition in the human cholangiocarcinoma CCKS-1 cell line. Oncology letters 2013;6:915-920.

[75] Okamoto K, Tajima H, Nakanuma S, Sakai S, Makino I, Kinoshita J, et al. Angiotensin II enhances epithelial-to-mesenchymal transition through the interaction between activated hepatic stellate cells and the stromal cell-derived factor-1/CXCR4 axis in intrahepatic cholangiocarcinoma. International journal of oncology 2012;41:573-582.

[76] Qiao P, Li G, Bi W, Yang L, Yao L, Wu D. microRNA-34a inhibits epithelial mesenchymal transition in human cholangiocarcinoma by targeting Smad4 through transforming growth factor-beta/Smad pathway. BMC cancer 2015;15:469.

[77] Ling H, Roux E, Hempel D, Tao J, Smith M, Lonning S, et al. Transforming growth factor beta neutralization ameliorates pre-existing hepatic fibrosis and reduces cholangiocarcinoma in thioacetamide-treated rats. PloS one 2013;8:e54499.

[78] Xu YF, Ge FJ, Han B, Yang XQ, Su H, Zhao AC, et al. High-mobility group box 1 expression and lymph node metastasis in intrahepatic cholangiocarcinoma. World journal of gastroenterology : WJG 2015;21:3256-3265.

[79] Nitta T, Sato Y, Ren XS, Harada K, Sasaki M, Hirano S, et al. Autophagy may promote carcinoma cell invasion and correlate with poor prognosis in cholangiocarcinoma. International journal of clinical and experimental pathology 2014;7:4913-4921. 
[80] Boon MR, van der Horst G, van der Pluijm G, Tamsma JT, Smit JW, Rensen PC. Bone morphogenetic protein 7: a broad-spectrum growth factor with multiple target therapeutic potency. Cytokine \& growth factor reviews $2011 ; 22: 221-229$.

[81] Tanimura Y, Kokuryo T, Tsunoda N, Yamazaki Y, Oda K, Nimura Y, et al. Tumor necrosis factor alpha promotes invasiveness of cholangiocarcinoma cells via its receptor, TNFR2. Cancer letters 2005;219:205-213.

[82] Itatsu K, Sasaki M, Harada K, Yamaguchi J, Ikeda H, Sato Y, et al. Phosphorylation of extracellular signal-regulated kinase 1/2, p38 mitogen-activated protein kinase and nuclear translocation of nuclear factor-kappaB are involved in upregulation of matrix metalloproteinase-9 by tumour necrosis factor-alpha. Liver international : official journal of the International Association for the Study of the Liver 2009;29:291-298.

[83] Yokomuro S, Tsuji H, Lunz JG, 3rd, Sakamoto T, Ezure T, Murase N, et al. Growth control of human biliary epithelial cells by interleukin 6, hepatocyte growth factor, transforming growth factor beta1, and activin A: comparison of a cholangiocarcinoma cell line with primary cultures of non-neoplastic biliary epithelial cells. Hepatology 2000;32:26-35.

[84] Nehls O, Gregor M, Klump B. Serum and bile markers for cholangiocarcinoma. Seminars in liver disease 2004;24:139-154.

[85] Zhou QX, Jiang XM, Wang ZD, Li CL, Cui YF. Enhanced expression of suppresser of cytokine signaling 3 inhibits the IL-6-induced epithelial-to-mesenchymal transition and cholangiocarcinoma cell metastasis. Medical oncology 2015;32:105.

[86] Claperon A, Guedj N, Mergey M, Vignjevic D, Desbois-Mouthon C, Boissan M, et al. Loss of EBP50 stimulates EGFR activity to induce EMT phenotypic features in biliary cancer cells. Oncogene 2012;31:1376-1388.

[87] Yoon JH, Gwak GY, Lee HS, Bronk SF, Werneburg NW, Gores GJ. Enhanced epidermal growth factor receptor activation in human cholangiocarcinoma cells. Journal of hepatology 2004;41:808-814. 
[88] Sia D, Hoshida Y, Villanueva A, Roayaie S, Ferrer J, Tabak B, et al. Integrative molecular analysis of intrahepatic cholangiocarcinoma reveals 2 classes that have different outcomes. Gastroenterology 2013;144:829-840.

[89] Lee MJ, Yu GR, Yoo HJ, Kim JH, Yoon BI, Choi YK, et al. ANXA8 down-regulation by EGF-FOXO4 signaling is involved in cell scattering and tumor metastasis of cholangiocarcinoma. Gastroenterology 2009;137:1138-1150, 1150 e1131-1139.

[90] Wang W, Zhang J, Zhan X, Lin T, Yang M, Hu J, et al. SOX4 is associated with poor prognosis in cholangiocarcinoma. Biochemical and biophysical research communications 2014;452:614-621.

[91] Khansaard W, Techasen A, Namwat N, Yongvanit P, Khuntikeo N, Puapairoj A, et al. Increased EphB2 expression predicts cholangiocarcinoma metastasis. Tumour biology : the journal of the International Society for Oncodevelopmental Biology and Medicine 2014;35:10031-10041.

[92] Cui XD, Lee MJ, Kim JH, Hao PP, Liu L, Yu GR, et al. Activation of mammalian target of rapamycin complex 1 (mTORC1) and Raf/Pyk2 by growth factor-mediated Eph receptor 2 (EphA2) is required for cholangiocarcinoma growth and metastasis. Hepatology 2013;57:2248-2260.

[93] Francis H, Meng F, Gaudio E, Alpini G. Histamine regulation of biliary proliferation. Journal of hepatology 2012;56:1204-1206.

[94] Meng F, Han Y, Staloch D, Francis T, Stokes A, Francis H. The H4 histamine receptor agonist, clobenpropit, suppresses human cholangiocarcinoma progression by disruption of epithelial mesenchymal transition and tumor metastasis. Hepatology 2011;54:1718-1728.

[95] Gentilini A, Rombouts K, Galastri S, Caligiuri A, Mingarelli E, Mello T, et al. Role of the stromal-derived factor-1 (SDF-1)-CXCR4 axis in the interaction between hepatic stellate cells and cholangiocarcinoma. Journal of hepatology 2012;57:813-820. 
[96] Zhao S, Wang J, Qin C. Blockade of CXCL12/CXCR4 signaling inhibits intrahepatic cholangiocarcinoma progression and metastasis via inactivation of canonical Wnt pathway. Journal of experimental \& clinical cancer research : CR 2014;33:103.

[97] Ishimura N, Bronk SF, Gores GJ. Inducible nitric oxide synthase up-regulates Notch-1 in mouse cholangiocytes: implications for carcinogenesis. Gastroenterology 2005;128:13541368.

[98] Zhou Q, Wang Y, Peng B, Liang L, Li J. The roles of Notch1 expression in the migration of intrahepatic cholangiocarcinoma. BMC cancer 2013;13:244.

[99] Wu WR, Zhang R, Shi XD, Zhu MS, Xu LB, Zeng H, et al. Notch1 is overexpressed in human intrahepatic cholangiocarcinoma and is associated with its proliferation, invasiveness and sensitivity to 5-fluorouracil in vitro. Oncology reports 2014;31:2515-2524.

[100] Wu WR, Shi XD, Zhang R, Zhu MS, Xu LB, Yu XH, et al. Clinicopathological significance of aberrant Notch receptors in intrahepatic cholangiocarcinoma. International journal of clinical and experimental pathology 2014;7:3272-3279.

[101] Yoon HA, Noh MH, Kim BG, Han JS, Jang JS, Choi SR, et al. Clinicopathological significance of altered Notch signaling in extrahepatic cholangiocarcinoma and gallbladder carcinoma. World journal of gastroenterology : WJG 2011;17:4023-4030.

[102] El Khatib M, Bozko P, Palagani V, Malek NP, Wilkens L, Plentz RR. Activation of Notch signaling is required for cholangiocarcinoma progression and is enhanced by inactivation of p53 in vivo. PloS one 2013;8:e77433.

[103] Delous M, Yin C, Shin D, Ninov N, Debrito Carten J, Pan L, et al. Sox9b is a key regulator of pancreaticobiliary ductal system development. PLoS genetics 2012;8:e1002754.

[104] Villanueva A, Alsinet C, Yanger K, Hoshida Y, Zong Y, Toffanin S, et al. Notch signaling is activated in human hepatocellular carcinoma and induces tumor formation in mice. Gastroenterology 2012;143:1660-1669 e1667.

[105] Matsushima H, Kuroki T, Kitasato A, Adachi T, Tanaka T, Hirabaru M, et al. Sox9 expression in carcinogenesis and its clinical significance in intrahepatic cholangiocarcinoma. 
Digestive and liver disease : official journal of the Italian Society of Gastroenterology and the Italian Association for the Study of the Liver 2015;47:1067-1075.

[106] Capaccione KM, Hong X, Morgan KM, Liu W, Bishop JM, Liu L, et al. Sox9 mediates Notch1-induced mesenchymal features in lung adenocarcinoma. Oncotarget 2014;5:36363650.

[107] El Khatib M, Kalnytska A, Palagani V, Kossatz U, Manns MP, Malek NP, et al. Inhibition of hedgehog signaling attenuates carcinogenesis in vitro and increases necrosis of cholangiocellular carcinoma. Hepatology 2013;57:1035-1045.

[108] Tang L, Tan YX, Jiang BG, Pan YF, Li SX, Yang GZ, et al. The prognostic significance and therapeutic potential of hedgehog signaling in intrahepatic cholangiocellular carcinoma. Clinical cancer research : an official journal of the American Association for Cancer Research 2013;19:2014-2024.

[109] Al-Bahrani R, Nagamori S, Leng R, Petryk A, Sergi C. Differential Expression of Sonic Hedgehog Protein in Human Hepatocellular Carcinoma and Intrahepatic Cholangiocarcinoma. Pathology oncology research : POR 2015.

[110] Wutka A, Palagani V, Barat S, Chen X, El Khatib M, Gotze J, et al. Capsaicin treatment attenuates cholangiocarcinoma carcinogenesis. PloS one 2014;9:e95605.

[111] Li J, Yao L, Li G, Ma D, Sun C, Gao S, et al. miR-221 Promotes EpithelialMesenchymal Transition through Targeting PTEN and Forms a Positive Feedback Loop with beta-catenin/c-Jun Signaling Pathway in Extra-Hepatic Cholangiocarcinoma. PloS one 2015;10:e0141168.

[112] Oishi N, Kumar MR, Roessler S, Ji J, Forgues M, Budhu A, et al. Transcriptomic profiling reveals hepatic stem-like gene signatures and interplay of miR-200c and epithelialmesenchymal transition in intrahepatic cholangiocarcinoma. Hepatology 2012;56:1792-1803.

[113] Qiu YH, Wei YP, Shen NJ, Wang ZC, Kan T, Yu WL, et al. miR-204 inhibits epithelial to mesenchymal transition by targeting slug in intrahepatic cholangiocarcinoma cells. Cellular physiology and biochemistry : international journal of experimental cellular physiology, biochemistry, and pharmacology 2013;32:1331-1341. 
[114] Li B, Han Q, Zhu Y, Yu Y, Wang J, Jiang X. Down-regulation of miR-214 contributes to intrahepatic cholangiocarcinoma metastasis by targeting Twist. The FEBS journal 2012;279:2393-2398.

[115] Liu Z, Jin ZY, Liu CH, Xie F, Lin XS, Huang Q. MicroRNA-21 regulates biological behavior by inducing EMT in human cholangiocarcinoma. International journal of clinical and experimental pathology 2015;8:4684-4694.

[116] Fukase K, Ohtsuka H, Onogawa T, Oshio H, li T, Mutoh M, et al. Bile acids repress Ecadherin through the induction of Snail and increase cancer invasiveness in human hepatobiliary carcinoma. Cancer science 2008;99:1785-1792.

[117] Werneburg NW, Yoon JH, Higuchi H, Gores GJ. Bile acids activate EGF receptor via a TGF-alpha-dependent mechanism in human cholangiocyte cell lines. American journal of physiology Gastrointestinal and liver physiology 2003;285:G31-36.

[118] Balsano C, Conti B, Arciello M. Regarding: epithelial-mesenchymal transition induced by hepatitis $\mathrm{C}$ virus core protein in cholangiocarcinoma. Annals of surgical oncology 2011;18:896; author reply 897.

[119] Li T, Li D, Cheng L, Wu H, Gao Z, Liu Z, et al. Epithelial-mesenchymal transition induced by hepatitis $\mathrm{C}$ virus core protein in cholangiocarcinoma. Annals of surgical oncology $2010 ; 17: 1937-1944$.

[120] Demetris AJ, Specht S, Nozaki I, Lunz JG, 3rd, Stolz DB, Murase N, et al. Small proline-rich proteins (SPRR) function as SH3 domain ligands, increase resistance to injury and are associated with epithelial-mesenchymal transition (EMT) in cholangiocytes. Journal of hepatology 2008;48:276-288.

[121] Yang Y, Liu Y, He JC, Wang JM, Schemmer P, Ma CQ, et al. 14-3-3zeta and aPKCiota synergistically facilitate epithelial-mesenchymal transition of cholangiocarcinoma via GSK-3beta/snail signaling pathway. Oncotarget 2016.

[122] Zhang C, Liu LX, Dong ZR, Shi GM, Cai JB, Zhang PF, et al. Up-regulation of 14-33zeta expression in intrahepatic cholangiocarcinoma and its clinical implications. Tumour 
biology : the journal of the International Society for Oncodevelopmental Biology and Medicine 2015;36:1781-1789.

[123] Zhou C, Zheng Y, Li L, Zhai W, Li R, Liang Z, et al. Adrenomedullin promotes intrahepatic cholangiocellular carcinoma metastasis and invasion by inducing epithelialmesenchymal transition. Oncology reports 2015;34:610-616.

[124] Watanabe A, Suzuki H, Yokobori T, Altan B, Kubo N, Araki K, et al. Forkhead box protein C2 contributes to invasion and metastasis of extrahepatic cholangiocarcinoma, resulting in a poor prognosis. Cancer science 2013;104:1427-1432.

[125] Zhu Z, Chen W, Yin X, Lai J, Wang Q, Liang L, et al. WAVE3 Induces EMT and Promotes Migration and Invasion in Intrahepatic Cholangiocarcinoma. Digestive diseases and sciences 2016 .

[126] Xu YF, Yang XQ, Lu XF, Guo S, Liu Y, lqbal M, et al. Fibroblast growth factor receptor 4 promotes progression and correlates to poor prognosis in cholangiocarcinoma. Biochemical and biophysical research communications 2014;446:54-60.

[127] Yang H, Lu X, Liu Z, Chen L, Xu Y, Wang Y, et al. FBXW7 suppresses epithelialmesenchymal transition, stemness and metastatic potential of cholangiocarcinoma cells. Oncotarget 2015;6:6310-6325.

[128] Enkhbold C, Utsunomiya T, Morine Y, Imura S, Ikemoto T, Arakawa Y, et al. Loss of FBXW7 expression is associated with poor prognosis in intrahepatic cholangiocarcinoma. Hepatology research : the official journal of the Japan Society of Hepatology 2014;44:E346352.

[129] Sribenja S, Sawanyawisuth K, Kraiklang R, Wongkham C, Vaeteewoottacharn K, Obchoei S, et al. Suppression of thymosin beta10 increases cell migration and metastasis of cholangiocarcinoma. BMC cancer 2013;13:430.

[130] Yang LX, Gao Q, Shi JY, Wang ZC, Zhang Y, Gao PT, et al. Mitogen-activated protein kinase kinase kinase 4 deficiency in intrahepatic cholangiocarcinoma leads to invasive growth and epithelial-mesenchymal transition. Hepatology 2015;62:1804-1816. 
[131] Sirica AE. The role of cancer-associated myofibroblasts in intrahepatic cholangiocarcinoma. Nature reviews Gastroenterology \& hepatology 2012;9:44-54.

[132] Chu AS, Diaz R, Hui JJ, Yanger K, Zong Y, Alpini G, et al. Lineage tracing demonstrates no evidence of cholangiocyte epithelial-to-mesenchymal transition in murine models of hepatic fibrosis. Hepatology 2011;53:1685-1695.

[133] Cadamuro M, Nardo G, Indraccolo S, Dall'olmo L, Sambado L, Moserle L, et al. Platelet-derived growth factor-D and Rho GTPases regulate recruitment of cancerassociated fibroblasts in cholangiocarcinoma. Hepatology 2013;58:1042-1053.

[134] Ohira S, Sasaki M, Harada K, Sato Y, Zen Y, Isse K, et al. Possible regulation of migration of intrahepatic cholangiocarcinoma cells by interaction of CXCR4 expressed in carcinoma cells with tumor necrosis factor-alpha and stromal-derived factor-1 released in stroma. The American journal of pathology 2006;168:1155-1168.

[135] Hasita H, Komohara Y, Okabe H, Masuda T, Ohnishi K, Lei XF, et al. Significance of alternatively activated macrophages in patients with intrahepatic cholangiocarcinoma. Cancer science 2010;101:1913-1919.

[136] Thanee M, Loilome W, Techasen A, Namwat N, Boonmars T, Pairojkul C, et al. Quantitative changes in tumor-associated M2 macrophages characterize cholangiocarcinoma and their association with metastasis. Asian Pacific journal of cancer prevention : APJCP 2015;16:3043-3050.

[137] Boulter L, Guest RV, Kendall TJ, Wilson DH, Wojtacha D, Robson AJ, et al. WNT signaling drives cholangiocarcinoma growth and can be pharmacologically inhibited. The Journal of clinical investigation 2015;125:1269-1285.

[138] Vincan E, Barker N. The upstream components of the Wnt signalling pathway in the dynamic EMT and MET associated with colorectal cancer progression. Clinical \& experimental metastasis 2008;25:657-663.

[139] Arend RC, Londono-Joshi AI, Straughn JM, Jr., Buchsbaum DJ. The Wnt/betacatenin pathway in ovarian cancer: a review. Gynecologic oncology 2013;131:772-779. 
[140] Francis $\mathrm{H}$, Meininger CJ. A review of mast cells and liver disease: What have we learned? Digestive and liver disease : official journal of the Italian Society of Gastroenterology and the Italian Association for the Study of the Liver 2010;42:529-536.

[141] Johnson C, Huynh V, Hargrove L, Kennedy L, Graf-Eaton A, Owens J, et al. Inhibition of Mast Cell-Derived Histamine Decreases Human Cholangiocarcinoma Growth and Differentiation via c-Kit/Stem Cell Factor-Dependent Signaling. The American journal of pathology 2016;186:123-133.

[142] Mertens JC, Fingas CD, Christensen JD, Smoot RL, Bronk SF, Werneburg NW, et al. Therapeutic effects of deleting cancer-associated fibroblasts in cholangiocarcinoma. Cancer research 2013;73:897-907.

[143] Zhang K, Chen D, Wang X, Zhang S, Wang J, Gao Y, et al. RNA interference targeting slug increases cholangiocarcinoma cell sensitivity to cisplatin via upregulating PUMA. International journal of molecular sciences 2011;12:385-400.

[144] Kim S, Yao J, Suyama K, Qian X, Qian BZ, Bandyopadhyay S, et al. Slug promotes survival during metastasis through suppression of Puma-mediated apoptosis. Cancer research 2014;74:3695-3706.

[145] Findlay VJ, Wang C, Watson DK, Camp ER. Epithelial-to-mesenchymal transition and the cancer stem cell phenotype: insights from cancer biology with therapeutic implications for colorectal cancer. Cancer gene therapy 2014;21:181-187.

[146] Lu Z, Wang J, Zheng T, Liang Y, Yin D, Song R, et al. FTY720 inhibits proliferation and epithelial-mesenchymal transition in cholangiocarcinoma by inactivating STAT3 signaling. BMC cancer 2014;14:783.

[147] Xie Y, Wehrkamp CJ, Li J, Wang Y, Wang Y, Mott JL, et al. Delivery of miR-200c Mimic with Poly(amido amine) CXCR4 Antagonists for Combined Inhibition of Cholangiocarcinoma Cell Invasiveness. Molecular pharmaceutics 2016;13:1073-1080.

[148] Samatov TR, Tonevitsky AG, Schumacher U. Epithelial-mesenchymal transition: focus on metastatic cascade, alternative splicing, non-coding RNAs and modulating compounds. Molecular cancer 2013;12:107. 
[149] Wilson C, Nicholes K, Bustos D, Lin E, Song Q, Stephan JP, et al. Overcoming EMTassociated resistance to anti-cancer drugs via Src/FAK pathway inhibition. Oncotarget 2014;5:7328-7341.

[150] Vaquero J, Clapéron A, Mergey M, Desbois-Mouthon C, Praz F, Fouassier L. Longterm inhibition of EGFR in human cholangiocarcinoma cells leads to the induction of an epithelial to mesenchymal transition program and activation of Insulin/Insulin Growth Factor 1 Receptors. Journal of hepatology 2015;62:S797.

Author names in bold designate shared co-first authorship. 


\section{Figure legends}

\section{Figure 1.}

Cancer cell EMT events. The diagram shows a group of cells progressively engaged in EMT and the differential changes in epithelial and mesenchymal markers during this process. A typical epithelial sheet (A) contains polarized epithelial cells on top of a basement membrane. Cells are joined together by several cell-cell junctions, tight junctions, GAP junctions and adherens junctions containing E-cadherin/ $\beta$-catenin. (B) Upon stimuli, increment in the expression of EMT-inducing transcription factors (EMT-TFs) leads to the down-regulation and disassembly of cell-cell junctions with the consequent loss of epithelia integrity. (C) EMT-TFs stimulate a mesenchymal phenotype, which includes reorganization of the actin cytoskeleton and secretion of matrix metalloproteinases allowing the dissolution of the basement membrane and the mobility of the resulting mesenchymal-like cells. The different proteins expressed through EMT are listed in the box.

\section{Figure 2.}

Regulatory networks involved in EMT regulation in CCA. Cytokines (A), tyrosine kinase receptors (B), G protein coupled receptors (C) and receptors involved in developmental processes (D) play a role in the induction of EMT program by activating intracellular signaling pathways in CCA tumor cells. miRNAs target several EMT regulatory proteins (E). Abbreviations: CXCR4, chemokine receptor type 4; EBP50, ezrin-radixin-moesin-binding phosphoprotein 50; EGF, epidermal growth factor; EGFR, epidermal growth factor receptor; EMT, epithelial-mesenchymal transition; EphA2, ephrin type-A receptor 2; GLI, gliomaassociated oncogene; H4HR, H4 histamine receptor; HB-EGF, heparin-binding EGF-like growth factor; IL, interleukin; ILR, interleukin receptor; miR, microRNA; NICD, notch intracellular domain; PTCH, patched receptor; SDF-1, stromal cell-derived factor 1; SMO, smoothened; SOX4, sex determining region $\mathrm{Y}$ box 4; SOX9, sex determining region $\mathrm{Y}$ box 9; Sp1, specificity protein 1; STAT3, signal transducer and activator of transcription 3; TGF- $\beta$, transforming-growth factor- $\beta$; TGF $\beta$ R, transforming-growth factor- $\beta$ receptor; TNF- $\alpha$, tumor 
necrosis factor- $\alpha$; TNFR, tumor necrosis factor receptor; ZEB, zinc finger E-box binding homeobox.

\section{Figure 3.}

Model depicting the reciprocal paracrine loop between CCA cells and cells from the tumor microenvironment involved in EMT regulation. (A) Hepatic myofibroblasts produce the EGFR ligand, HB-EGF, which activates EGFR at the CCA cell surface. EGFR activation leads to the stimulation of its downstream pathways and eventually to the activation of an EMT program. In addition, EGFR signaling also triggers TGF- $\beta$ production by CCA cells, which results in myofibroblast activation and in increased HB-EGF synthesis by myofibroblasts. Hepatic stellate cells produce SDF-1, which, together with ANGII induce $\beta$ catenin nuclear translocation through their receptors. Furthermore, both SDF-1 and ANGII are able to promote hepatic stellate cell activation. (B) LPS activated macrophages produce different factors, including several ILs, TGF- $\beta$, TNF- $\alpha$ and WNT ligands that promote EMT by signaling through their receptors. Recruited mast cells release histamine that induce EMT in CCA cells through HRs signaling. In turn, CCA cells produce SCF that promote mast cell migration and recruitment. Each color indicates a group of signaling pathways described in the text. Abbreviations: ANGII, angiotensin II; AT1, angiotensin II receptor type 1; CXCR4, chemokine receptor type 4; EGFR, epidermal growth factor receptor; EMT, epithelialmesenchymal transition; FDZ, frizzled receptor, HB-EGF, heparin-binding EGF-like growth factor; HRs, histamine receptors; IL, interleukin; ILR, interleukin receptor; LPS, lipopolysaccharide; SCF, stem cell factor; SDF-1, stromal cell-derived factor 1 ; TGF- $\beta$, transforming-growth factor- $\beta$; TGF $\beta R$, Transforming-growth factor- $\beta$ receptor; TNF- $\alpha$, tumor necrosis factor- $\alpha$; TNFR, tumor necrosis factor receptor. 
\begin{tabular}{l|l} 
Table 1 & Clinical relevance of EMT in human cholangiocarcinoma
\end{tabular}

\begin{tabular}{|c|c|c|c|c|c|c|}
\hline $\begin{array}{l}\text { Epithelial } \\
\text { markers }\end{array}$ & $\begin{array}{l}\text { CCA } \\
\text { subtype }\end{array}$ & $\begin{array}{l}\text { Number } \\
\text { of samples }\end{array}$ & $\begin{array}{l}\text { Membrane } \\
\text { expression/ } \\
\text { localization }\end{array}$ & $\begin{array}{l}\% \text { of } \\
\text { cases }\end{array}$ & $\begin{array}{l}\text { Association with } \\
\text { clinical parameters }\end{array}$ & Ref. \\
\hline \multirow[t]{19}{*}{ E-cadherin } & CCA & 35 & Reduced & 62.9 & $\begin{array}{l}\text { Tumor differentiation } \\
\text { Infiltration status } \\
\text { Lymph node metastasis } \\
\text { Clinical TNM staging } \\
\text { Median survival } \\
\text { Independent prognostic } \\
\text { factor in univariate and } \\
\text { multivariate analyses }\end{array}$ & [19] \\
\hline & CCA & 47 & Reduced & 45 & Tumor Grade & [20] \\
\hline & CCA & 83 & Reduced & 51.8 & Poor tumor differentiation & [26] \\
\hline & CCA & 140 & Reduced & 52 & Positive metastasis status & [28] \\
\hline & iCCA & 31 & Reduced & 61.3 & Not correlated & [21] \\
\hline & iCCA & 119 & Reduced & 41.2 & Not Correlated & [24] \\
\hline & iCCA & 96 & Reduced & 43.8 & $\begin{array}{l}\text { Lymph node metastasis } \\
\text { Advanced pTNM stage } \\
\text { Poor differentiation } \\
\text { Poorer overall survival } \\
\text { Independent prognostic } \\
\text { factor in multivariate analysis }\end{array}$ & [25] \\
\hline & iCCA & 83 & Reduced & 51.8 & $\begin{array}{l}\text { Poor histological } \\
\text { differentiation }\end{array}$ & [26] \\
\hline & iCCA & 100 & Cytoplasmic & 50 & $\begin{array}{l}\text { Tumor size } \\
\text { Presence of satellite nodules }\end{array}$ & [29] \\
\hline & iCCA & 85 & Reduced & 16.5 & Poor tumor differentiation & [31] \\
\hline & iCCA & 140 & Reduced & 55 & $\begin{array}{l}\text { Lymphatic metastasis } \\
\text { Poorer overall survival } \\
\text { Poorer disease free survival }\end{array}$ & [32] \\
\hline & iCCA & 102 & Reduced & 44.1 & Not correlated & [35] \\
\hline & iCCA & 42 & $\begin{array}{l}\text { Reduced } \\
\text { Absent }\end{array}$ & $\begin{array}{l}64.3 \\
19\end{array}$ & $\begin{array}{l}\text { Tumor grade } \\
\text { pTNM stage }\end{array}$ & [36] \\
\hline & & & & & $\begin{array}{l}\text { Intrahepatic metastasis } \\
\text { Poorer survival }\end{array}$ & \\
\hline & eCCA & 38 & Reduced & 42.1 & $\begin{array}{l}\text { Lymph node metastasis } \\
\text { Tumour stage }\end{array}$ & [18] \\
\hline & & & & & $\begin{array}{l}\text { Lymphatic invasion } \\
\text { Blood vessel invasion } \\
\text { Overal lower survival }\end{array}$ & \\
\hline & $\begin{array}{l}\text { eCCA } \\
\text { (pCCA) }\end{array}$ & 52 & Reduced & 36.5 & Not correlated & [37] \\
\hline & $\begin{array}{l}\text { eCCA } \\
(\mathrm{pCCA})\end{array}$ & 47 & Reduced & 40.4 & Not correlated & [39] \\
\hline & eCCA & 117 & Reduced & 82.1 & $\begin{array}{l}\text { Poorer overall survival } \\
\text { Independent prognostic } \\
\text { factor }\end{array}$ & [40] \\
\hline \multirow[t]{9}{*}{$\beta$-catenin } & CCA & 47 & Reduced & 58 & Tumor differentiation grade & [20] \\
\hline & iCCA & 31 & Nuclear & 16.1 & Not correlated & [21] \\
\hline & iCCA & 119 & Loss or delocalization & 57.1 & Not correlated & [24] \\
\hline & iCCA & 85 & Reduced / nuclear & 14.1 & $\begin{array}{l}\text { Poor tumor differentiation } \\
\text { Tumour size }\end{array}$ & [31] \\
\hline & ICCA & 140 & Cytoplasmic or nuclear & 45.7 & $\begin{array}{l}\text { Lymph node metastasis } \\
\text { Poorer overall survival }\end{array}$ & [32] \\
\hline & iCCA & 71 & $\begin{array}{l}\text { Reduced } \\
\text { Nuclear }\end{array}$ & $\begin{array}{l}82 \\
15\end{array}$ & Poor tumor differentiation & {$[44]$} \\
\hline & iCCA & 24 & Cytoplasmic or nuclear & 58.3 & Tumor size & [45] \\
\hline & iCCA & 38 & Reduced / cytoplasmic & 73.7 & Not correlated & [46] \\
\hline & eCCA & 79 & Nuclear & 12.6 & Not correlated & [47] \\
\hline
\end{tabular}




\begin{tabular}{|c|c|c|c|c|c|c|}
\hline CK19 & iCCA & 119 & Reduced & 42 & $\begin{array}{l}\text { Neural invasion } \\
\text { Intrahepatic metastasis } \\
\text { Undifferentiated tumor } \\
\text { Poor overall survival and } \\
\text { disease free survival }\end{array}$ & [24] \\
\hline $\begin{array}{l}\text { Mesenchymal } \\
\text { markers }\end{array}$ & $\begin{array}{l}\text { CCA } \\
\text { subtype }\end{array}$ & $\begin{array}{l}\text { Number } \\
\text { of samples }\end{array}$ & Expression & $\%$ & $\begin{array}{l}\text { Association with } \\
\text { clinical parameters }\end{array}$ & Ref. \\
\hline \multirow[t]{6}{*}{$\mathrm{N}$-cadherin } & CCA & 30 & Increased & 53.3 & Not correlated & [41] \\
\hline & iCCA & 96 & Increased & 57.3 & $\begin{array}{l}\text { Higher recurrence rate of } \\
\text { vascular invasion } \\
\text { Poorer overall survival }\end{array}$ & [25] \\
\hline & iCCA & 29 & Increased & 79 & Not correlated & [34] \\
\hline & eCCA & 38 & Increased & 23.7 & Not correlated & [18] \\
\hline & $\begin{array}{l}\text { eCCA } \\
\text { (pCCA) }\end{array}$ & 23 & Increased & 30.4 & Not correlated & [34] \\
\hline & eCCA & 117 & Increased & 18.8 & $\begin{array}{l}\text { Poorer overall survival } \\
\text { Independent prognostic } \\
\text { factor in multivariate analysis }\end{array}$ & [40] \\
\hline \multirow[t]{9}{*}{ Vimentin } & iCCA & 119 & Increased & 20.2 & Not correlated & [24] \\
\hline & iCCA & 96 & Increased & 37.5 & $\begin{array}{l}\text { Lymph node metastasis } \\
\text { Advanced pTNM stage } \\
\text { Poorly differentiated type } \\
\text { Poorer overall survival }\end{array}$ & [25] \\
\hline & iCCA & 85 & Increased & 21.2 & $\begin{array}{l}\text { Poor differentiation } \\
\text { Higher stage tumor }\end{array}$ & [31] \\
\hline & iCCA & 140 & Increased & 55.7 & $\begin{array}{l}\text { Lymphatic metastasis } \\
\text { Poorer overall survival } \\
\text { Poorer disease free survival }\end{array}$ & [32] \\
\hline & iCCA & 102 & Increased & 43.1 & $\begin{array}{l}\text { Portal vein invasion } \\
\text { Tumor size }\end{array}$ & [35] \\
\hline & iCCA & 23 & Increased & 69.6 & Not correlated & [49] \\
\hline & $\mathrm{iCCA}$ & 21 & Increased & 23.8 & $\begin{array}{l}\text { Tumor grade differentiation } \\
\text { Poorer overall survival } \\
\text { Independent prognostic } \\
\text { factor in multivariate analysis }\end{array}$ & [50] \\
\hline & eCCA & 117 & Increased & 13.7 & Poorer overall survival & [40] \\
\hline & $\begin{array}{l}\text { eCCA } \\
(\mathrm{pCCA})\end{array}$ & 17 & Increased & 11.8 & $\begin{array}{l}\text { Not correlated with clinico- } \\
\text { pathological features }\end{array}$ & [49] \\
\hline \multirow[t]{5}{*}{ S100A4 } & CCA & 86 & $\begin{array}{l}\text { Absent } \\
\text { Low nuclear } \\
\text { High nuclear }\end{array}$ & $\begin{array}{l}57 \\
22.1 \\
20.9\end{array}$ & $\begin{array}{l}\text { Overall survival after surgical } \\
\text { resection } \\
\text { Increased metastasis after } \\
\text { surgical resection }\end{array}$ & [54] \\
\hline & CCA & 50 & mRNA overexpression & 52 & Lymph node metastasis & [60] \\
\hline & iCCA & 119 & Increased & 30.3 & $\begin{array}{l}\text { Angiolymphatic invasion } \\
\text { Neural invasion } \\
\text { Intrahepatic metastasis } \\
\text { Undifferentiated tumor }\end{array}$ & [24] \\
\hline & iCCA & 65 & Increased & 49.2 & $\begin{array}{l}\text { Vascular invasion } \\
\text { Lymph node metastasis } \\
\text { TNM stage } \\
\text { Poorer overall survival rate } \\
\text { Independent prognostic } \\
\text { factor in multivariate analysis }\end{array}$ & [53] \\
\hline & eCCA & 117 & Increased & 11.1 & $\begin{array}{l}\text { Poorer overall survival } \\
\text { Independent prognostic } \\
\text { factor in multivariate analysis }\end{array}$ & [40] \\
\hline SNAIL & $\begin{array}{l}\text { CCA } \\
\text { iCCA }\end{array}$ & $\begin{array}{l}50 \\
119\end{array}$ & $\begin{array}{l}\text { mRNA overexpression } \\
\text { Increased }\end{array}$ & $\begin{array}{l}66 \\
28.6\end{array}$ & $\begin{array}{l}\text { Metastasis stage } \\
\text { Angiolymphatic invasion } \\
\text { Neural invasion } \\
\text { Intrahepatic metastasis }\end{array}$ & $\begin{array}{l}{[56]} \\
{[24]}\end{array}$ \\
\hline
\end{tabular}




\section{ACCEPTED MANUSCRIPT}

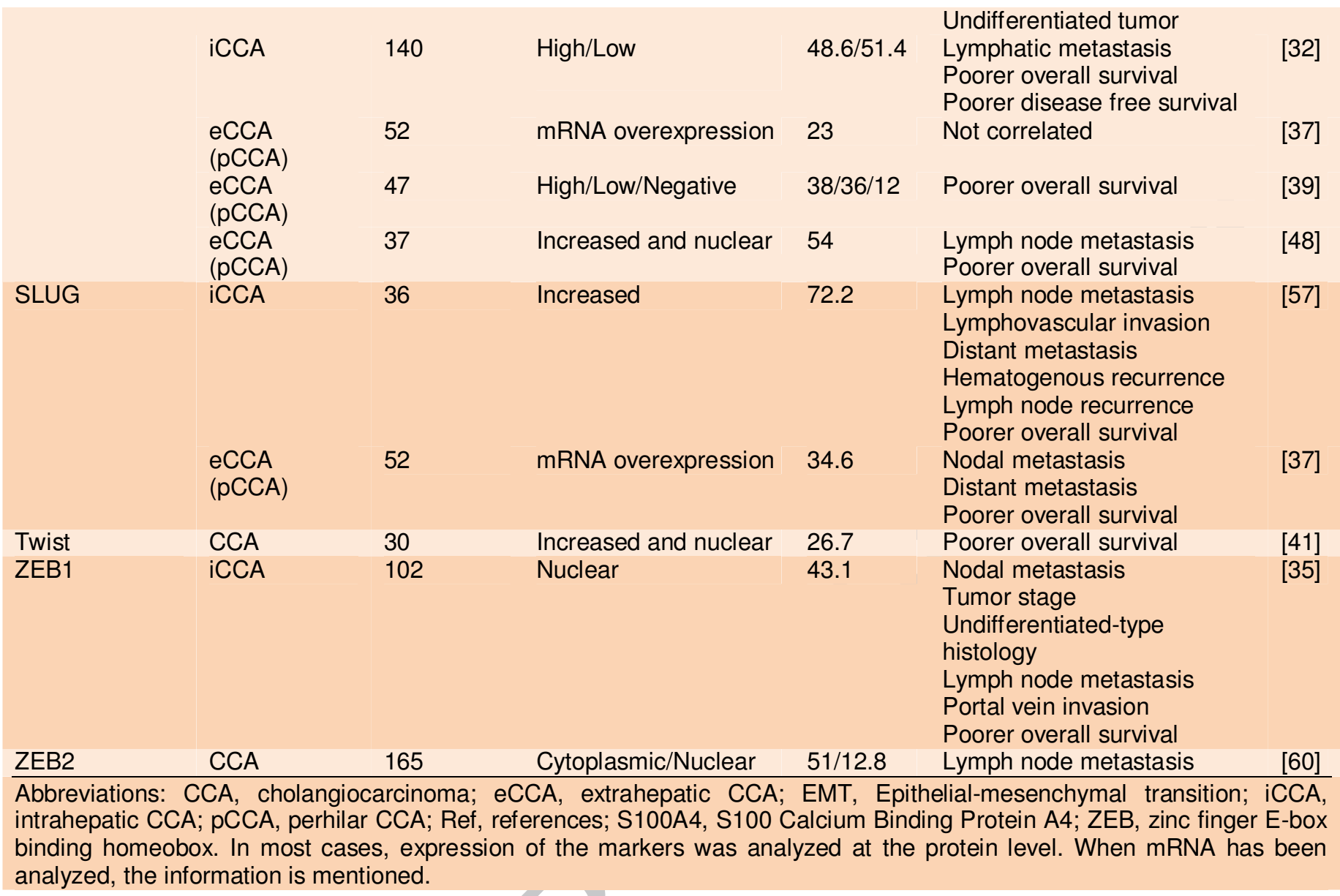


Table 2 Regulation of EMT in human cholangiocarcinoma cells

\begin{tabular}{|c|c|c|c|c|c|c|c|}
\hline $\begin{array}{l}\text { EMT } \\
\text { Inducer }\end{array}$ & $\begin{array}{l}\text { EMT } \\
\text { Inhibitor }\end{array}$ & $\begin{array}{l}\text { Receptor } \\
\text { /Target }\end{array}$ & $\begin{array}{l}\text { Epithelial } \\
\text { Marker }\end{array}$ & $\begin{array}{l}\text { Mesenchymal } \\
\text { Marker }\end{array}$ & $\begin{array}{l}\text { Biological } \\
\text { Effect }\end{array}$ & Cell lines & Ref. \\
\hline ADM & & Unknown & $\begin{array}{l}\text { E-cadherin } \\
\text { ZO-1 }\end{array}$ & $\begin{array}{l}\text { N-cadherin } \\
\text { Vimentin } \\
\text { ZEB1 }\end{array}$ & & $\begin{array}{l}\text { HuCC-T1 } \\
\text { HuH-28 }\end{array}$ & [123] \\
\hline ANGII & & AT1 & $\begin{array}{l}\beta \text {-catenin } \\
\text { E-cadherin }\end{array}$ & Vimentin & Migration & $\begin{array}{l}\text { CCKS-1 } \\
\text { HuCC-T1 }\end{array}$ & [75] \\
\hline \multirow[t]{4}{*}{ Bile acids } & & Unknown & E-cadherin & Snail & & HuCC-T1 & [116] \\
\hline & Capsaicin & $\begin{array}{l}\mathrm{Hh} \\
\text { signaling }\end{array}$ & E-cadherin & $\begin{array}{l}\mathrm{N} \text {-cadherin } \\
\text { Vimentin }\end{array}$ & $\begin{array}{l}\text { Invasion } \\
\text { Migration }\end{array}$ & $\begin{array}{l}\text { SZ1 } \\
\text { TFK-1 }\end{array}$ & [110] \\
\hline & Clobenpropit & $\mathrm{H} 4 \mathrm{HR}$ & $\begin{array}{l}\text { CK7 } \\
\text { CK8 } \\
\text { CK19 }\end{array}$ & $\begin{array}{l}\text { Fibronectin } \\
\text { MMP-1/-2/ } \\
-3 /-9 /-11 \\
\text { S100A4 } \\
\text { Vimentin }\end{array}$ & & $\mathrm{Mz}-\mathrm{ChA}-1$ & [94] \\
\hline & Cyclopamine & $\begin{array}{l}\text { Hh } \\
\text { signaling }\end{array}$ & E-cadherin & & $\begin{array}{l}\text { Invasion } \\
\text { Migration }\end{array}$ & $\begin{array}{l}\text { SZ1 } \\
\text { TFK-1 }\end{array}$ & [107] \\
\hline \multirow[t]{3}{*}{ EGF } & Gefitinib & EGFR & $\begin{array}{l}\beta \text {-catenin } \\
\text { DSP } 1 / 2 \\
\text { E-cadherin } \\
\text { ZO-1 }\end{array}$ & $\begin{array}{l}\alpha \text {-SMA } \\
\text { Fibronectin } \\
\text { MMP-1/-9 } \\
\text { N-cadherin } \\
\text { SLUG } \\
\text { Vimentin } \\
\text { ZEB-1 }\end{array}$ & $\begin{array}{l}\text { Invasion } \\
\text { Migration }\end{array}$ & $\begin{array}{l}\text { Choi-CK } \\
\text { Mz-ChA-1 } \\
\text { SK-ChA-1 }\end{array}$ & $\begin{array}{l}\text { [29] } \\
\text { [89] }\end{array}$ \\
\hline & FTY720 & $\begin{array}{l}\text { STAT3 } \\
\text { signaling }\end{array}$ & E-cadherin & $\begin{array}{l}\text { N-cadherin } \\
\text { TWIST1 } \\
\text { Vimentin }\end{array}$ & Invasion & $\begin{array}{l}\text { HuCC-T1 } \\
\text { QBC939 } \\
\text { TFK-1 }\end{array}$ & [146] \\
\hline & $\begin{array}{l}\gamma \text {-secretase } \\
\text { inhibitor }\end{array}$ & $\begin{array}{l}\text { Notch } \\
\text { signaling }\end{array}$ & $\begin{array}{l}\beta \text {-catenin } \\
\text { E-cadherin }\end{array}$ & $\begin{array}{l}\text { SNAIL } \\
\text { Vimentin }\end{array}$ & $\begin{array}{l}\text { Invasion } \\
\text { Migration }\end{array}$ & $\begin{array}{l}\text { SZ1 } \\
\text { TFK-1 }\end{array}$ & [102] \\
\hline FGF19 & AP24354 & FGFR4 & E-cadherin & $\begin{array}{l}\text { N-cadherin } \\
\text { SNAIL } \\
\text { Vimentin }\end{array}$ & Invasion & RBE & [126] \\
\hline HB-EGF & Gefitinib & EGFR & $\begin{array}{l}\beta \text {-catenin } \\
\text { E-cadherin }\end{array}$ & & $\begin{array}{l}\text { Invasion } \\
\text { Migration }\end{array}$ & $\begin{array}{l}\text { EGI-I } \\
\text { Mz-ChA-1 } \\
\text { SK-ChA-1 }\end{array}$ & [68] \\
\hline Histamine & $\begin{array}{l}\text { Cromolyn } \\
\text { sodium }\end{array}$ & HR & E-cadherin & $\begin{array}{l}\text { Paxilin } \\
\text { S100A4 } \\
\text { Vimentin } \\
\text { MMP-2/-3/-9 }\end{array}$ & & $\mathrm{Mz}-\mathrm{ChA}-1$ & [141] \\
\hline \multirow[t]{2}{*}{ IL-6 } & & IL6R & E-cadherin & $\begin{array}{l}\text { N-cadherin } \\
\text { SNAIL } \\
\text { Vimentin }\end{array}$ & $\begin{array}{l}\text { Invasion } \\
\text { Migration }\end{array}$ & $\begin{array}{l}\text { CCLP1 } \\
\text { HCCC9810 } \\
\text { HuCC-T1 } \\
\text { KMCH } \\
\text { Mz-ChA-1 } \\
\text { RBE }\end{array}$ & $\begin{array}{l}{[71]} \\
{[85]}\end{array}$ \\
\hline & PCX/miR200c & $\begin{array}{l}\text { CXCR4/ } \\
\text { ZEB1 }\end{array}$ & & ZEB1 & Migration & HuCC-T1 & [147] \\
\hline SDF1 & AMD3100 & CXCR4 & $\begin{array}{l}\beta \text {-catenin } \\
\text { E-cadherin }\end{array}$ & $\begin{array}{l}\text { MMP-9 } \\
\text { SLUG } \\
\text { Vimentin }\end{array}$ & $\begin{array}{l}\text { Invasion } \\
\text { Migration }\end{array}$ & $\begin{array}{l}\text { CCKS-1 } \\
\text { HuCC-T1 }\end{array}$ & $\begin{array}{l}{[95]} \\
{[96]} \\
{[75]}\end{array}$ \\
\hline TGF- $\beta$ & $\begin{array}{l}\text { BMP-7 } \\
\text { Paclitaxel } \\
\text { TGF- } \beta \text { sRII }\end{array}$ & TGF $\beta R$ & $\begin{array}{l}\beta \text {-catenin } \\
\text { CK19 } \\
\text { E-cadherin }\end{array}$ & $\begin{array}{l}\alpha \text {-SMA } \\
\text { Col1A1 } \\
\text { Fibronectin } \\
\text { MMP-2 } \\
\text { N-cadherin } \\
\text { S100A4 } \\
\text { SNAIL } \\
\text { TWIST } \\
\text { Vimentin }\end{array}$ & $\begin{array}{l}\text { Invasion } \\
\text { Migration }\end{array}$ & $\begin{array}{l}\text { BECs } \\
\text { CCKS-1 } \\
\text { CCLP1 } \\
\text { GBC-SD } \\
\text { HuCC-T1 } \\
\text { KMCH } \\
\text { M139 } \\
\text { M213 } \\
\text { Mz-ChA-1 }\end{array}$ & $\begin{array}{l}{[18]} \\
{[41]} \\
{[48]} \\
{[69]} \\
{[74]} \\
{[76]} \\
{[75]}\end{array}$ \\
\hline
\end{tabular}




\begin{tabular}{|c|c|c|c|c|c|c|}
\hline TNF- $\alpha$ & TNFR & $\begin{array}{l}\text { CK19 } \\
\text { E-cadherin }\end{array}$ & $\begin{array}{l}\text { MMP-9 } \\
\text { S100A4 } \\
\text { SNAIL } \\
\text { Vimentin } \\
\text { ZEB2 }\end{array}$ & $\begin{array}{l}\text { Invasion } \\
\text { Migration }\end{array}$ & $\begin{array}{l}\text { CCKS-1 } \\
\text { HuCC-T1 } \\
\text { M139 } \\
\text { M213 } \\
\text { M214 }\end{array}$ & $\begin{array}{l}{[56]} \\
{[60]} \\
{[81]} \\
{[82]}\end{array}$ \\
\hline WNT3 & $\begin{array}{l}\beta \text {-catenin } \\
\text { signaling }\end{array}$ & $\beta$-catenin & & & M214 & [46] \\
\hline
\end{tabular}

Abbreviations: ADM, adrenomedullin; ANGII, angiotensin II; AT1, angiotensin II receptor type 1; BMP-7, bone morphogenetic protein-7; CK, cytokeratin; CXCR4, chemokine receptor type 4; DSP, desmoplakin; EGF, epidermal growth factor; FGF19, fibroblast growth factor 19; FTY720, fingolimod; HB-EGF, heparin-binding EGF-like growth factor; Hh, hedgehog; HR, histamine receptor; IL, interleukin; MMP, matrix metalloproteinase; Ref, references; S100A4, S100 Calcium Binding Protein A4; SDF-1, stromal cell-derived factor 1 ; TGF- $\beta$, transforminggrowth factor- $\beta$; TGF- $\beta$ sRII, soluble TGF- $\beta$ type II receptor; TNF- $\alpha$, tumor necrosis factor- $\alpha$; WNT3, wingless-Type MMTV Integration Site Family, Member 3; ZO-1, zonula occludens 1. 
A

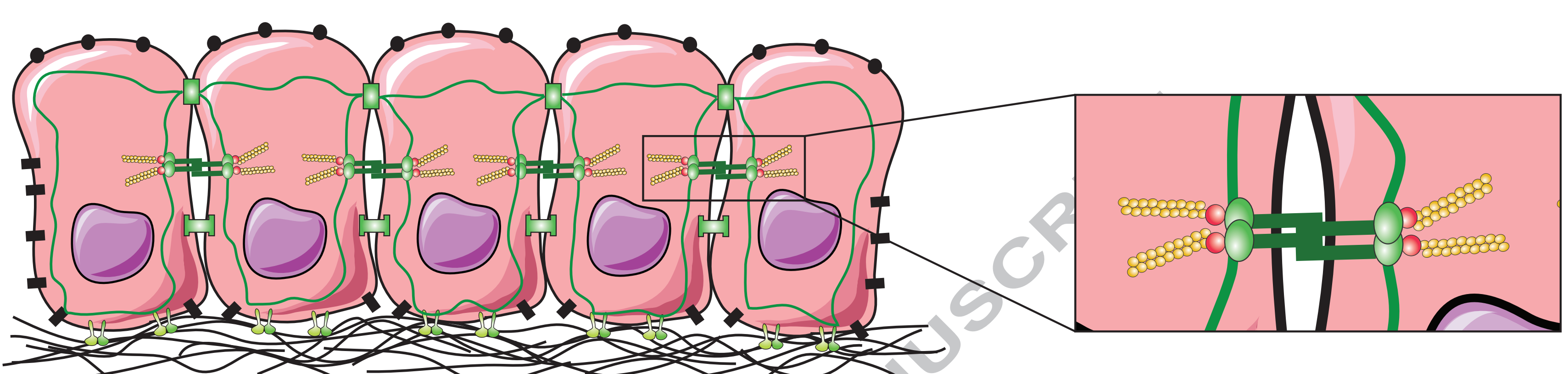

EMT stimulus

EMT-TFs increment

E-cadherin deregulation

Loss of Apico-Basal polarity

B

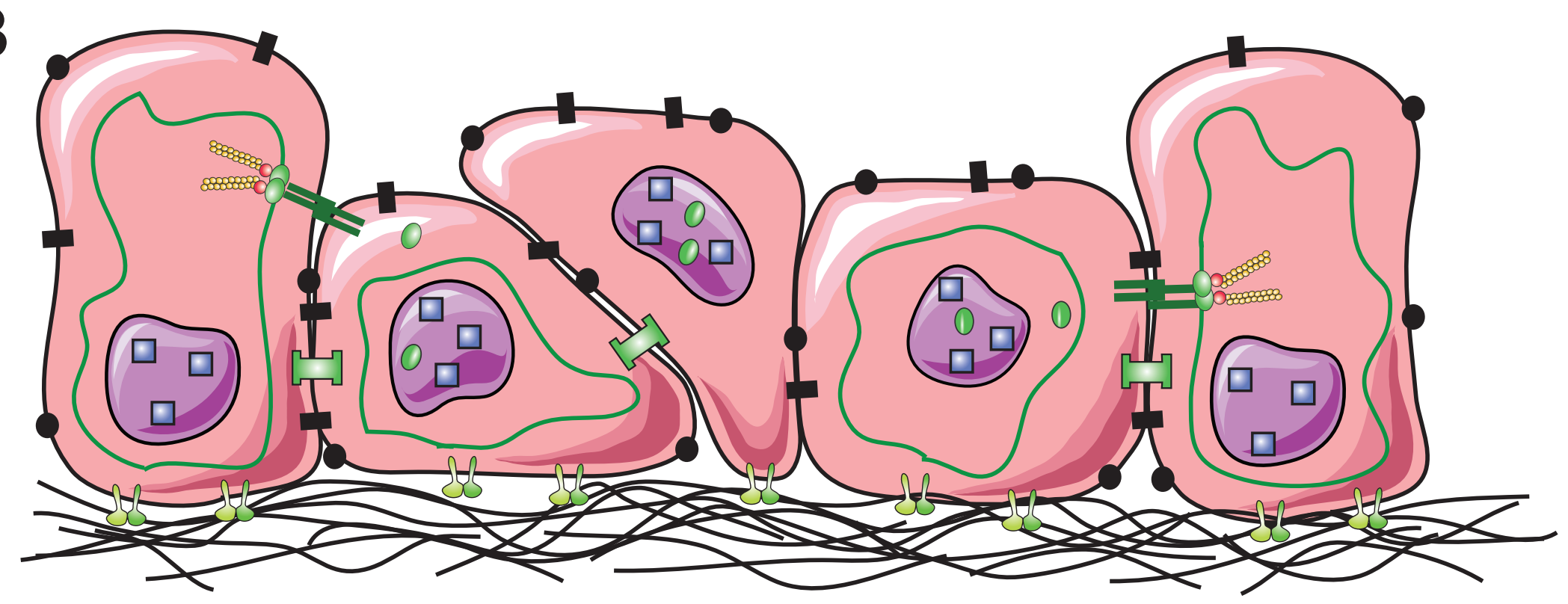

Gain of mesenchymal proteins

Migration and invasion

C

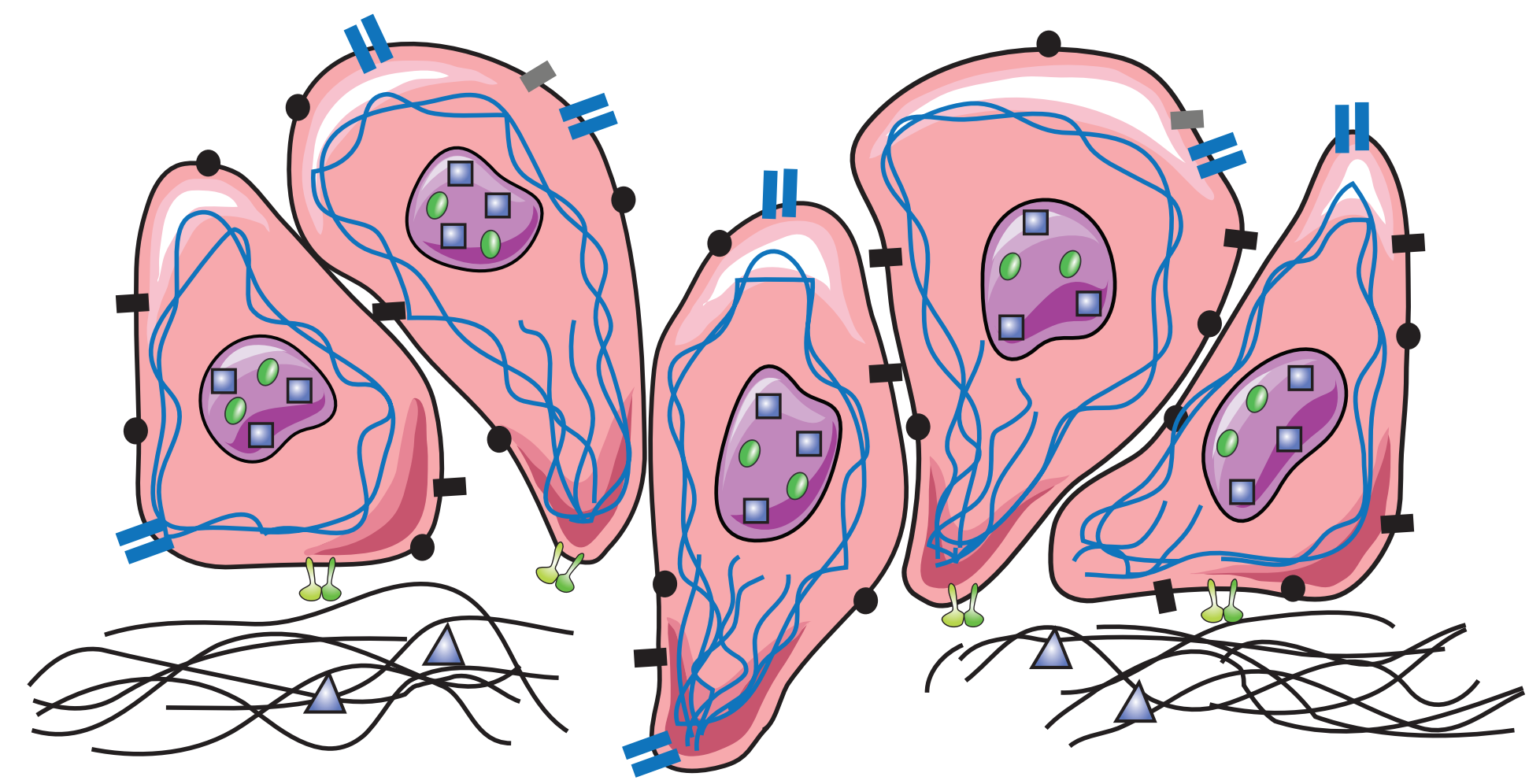

$\frown$ Basement membrane

Apical membrane components

Basolateral membrane components

Integrins

Cytokeratin intermediate filaments

GAP junctions

$\square \quad$ Tight junctions

E-cadherin

$0 \quad \beta$-catenin

- a-catenin

Actin cytoskeleton

Vimentin

EMT-inducing transcriptional factors

$\triangle \quad$ Matrix metalloproteinases

N-cadherin 


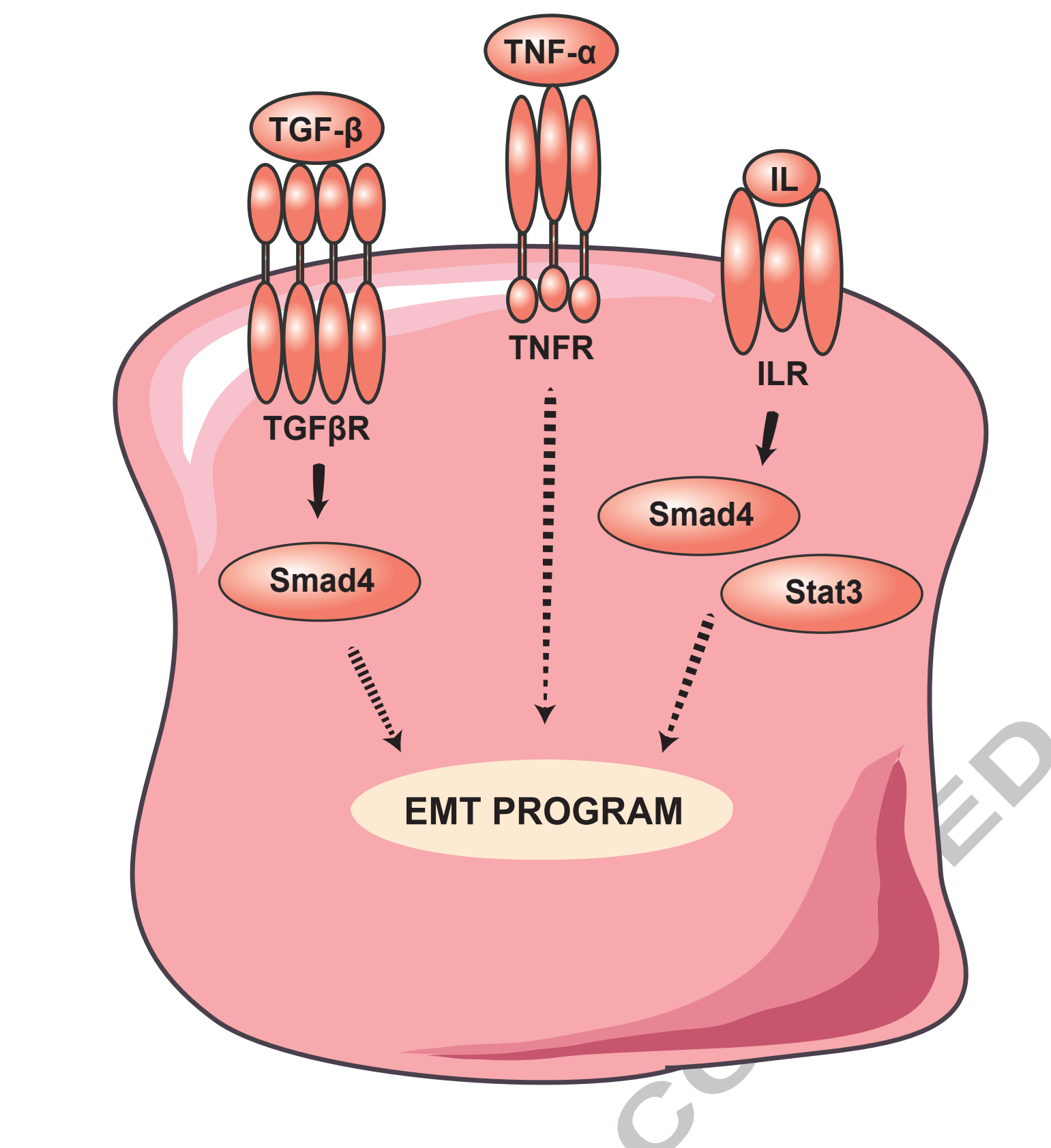

C. G protein coupled receptors

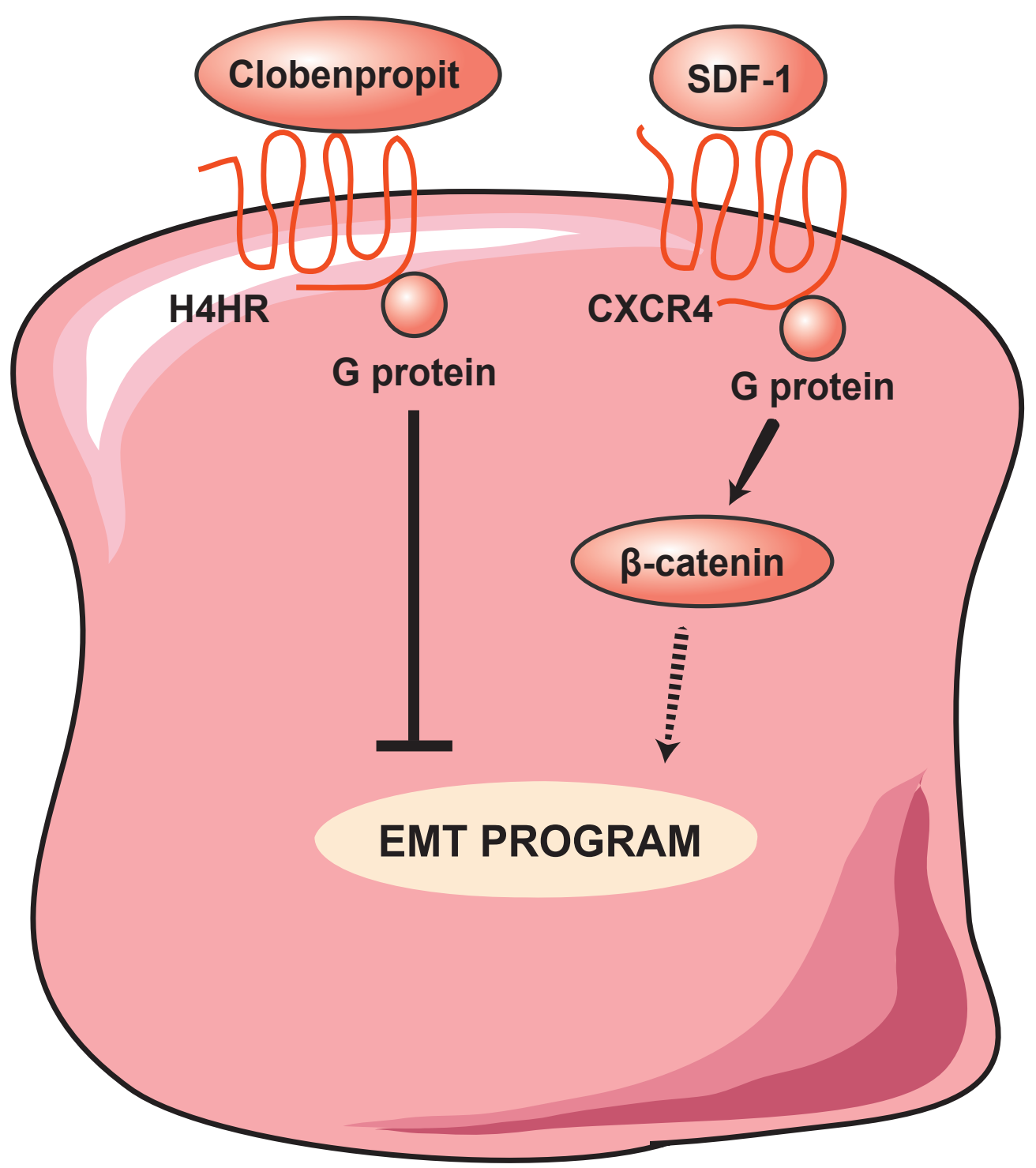

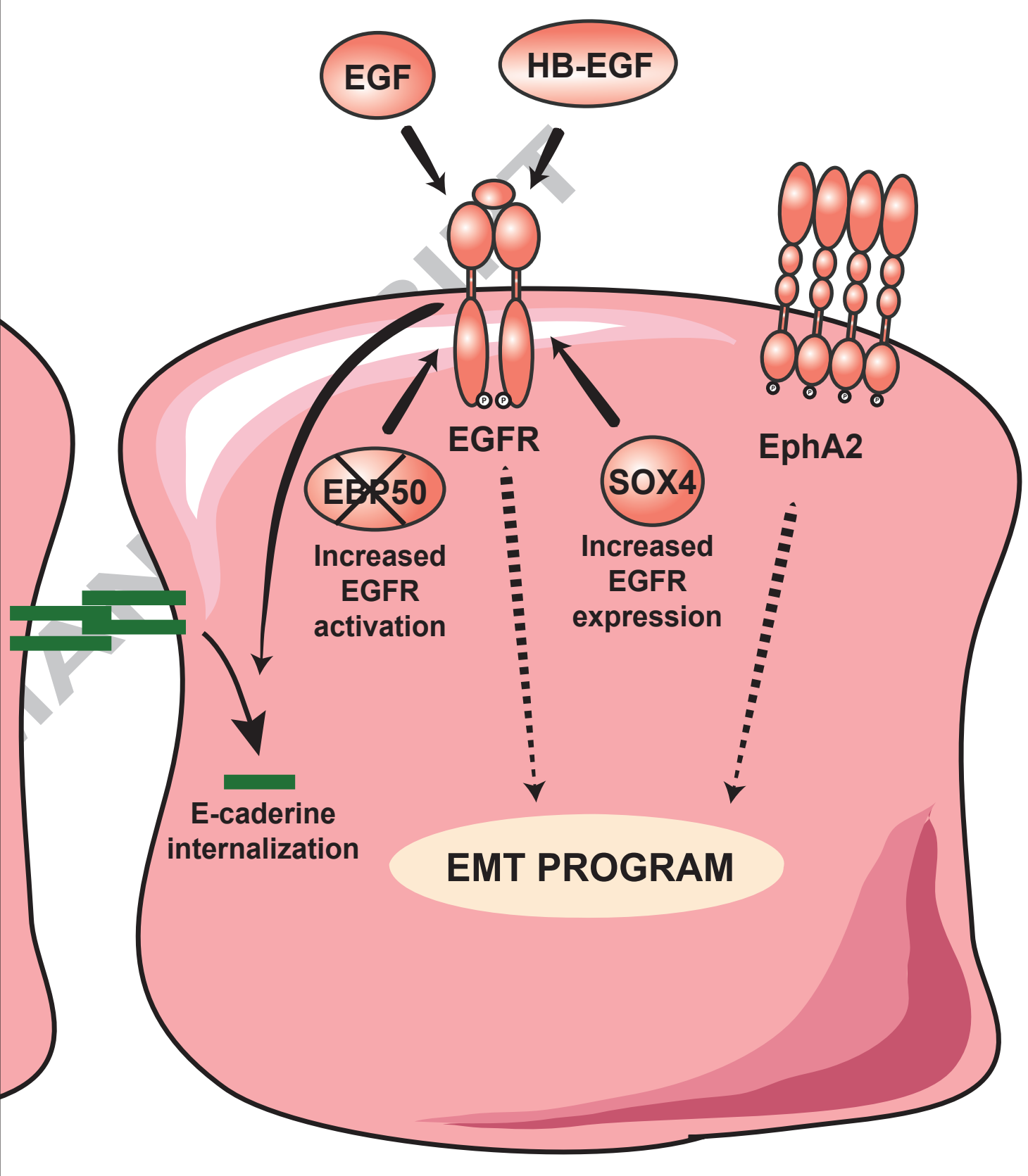

D. Development-related pathways

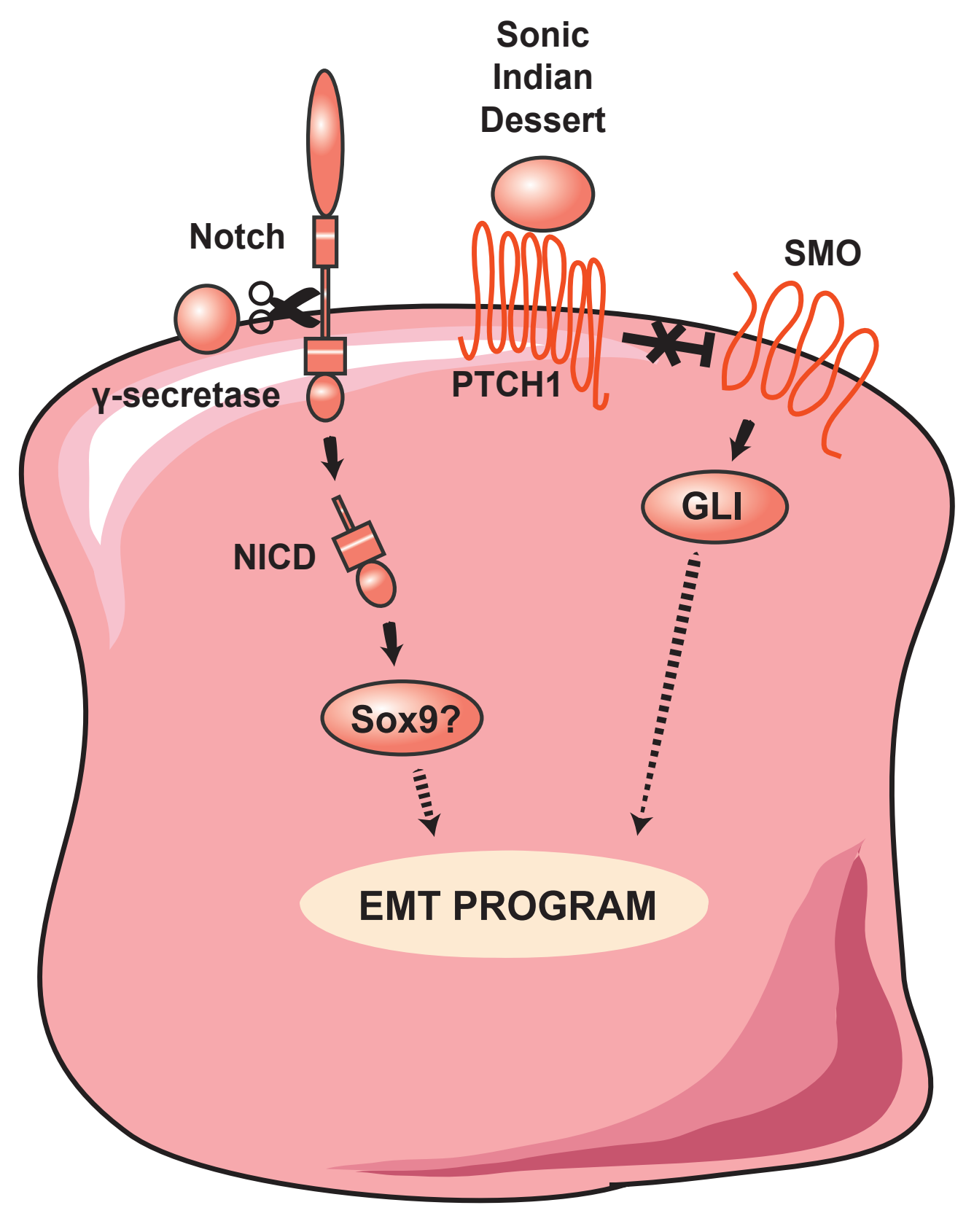

E. miRNAs

EMT inhibition

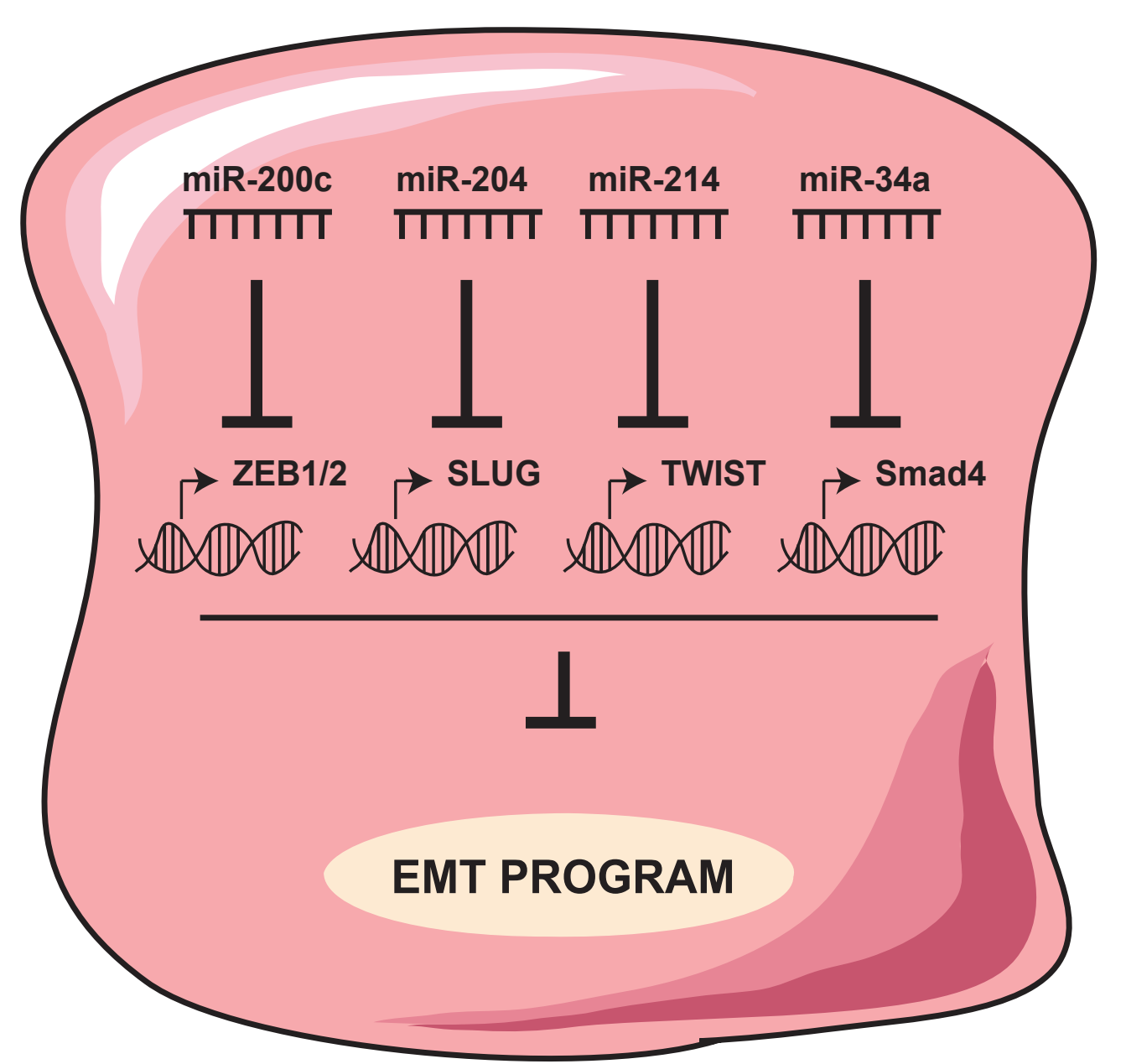

EMT Activation

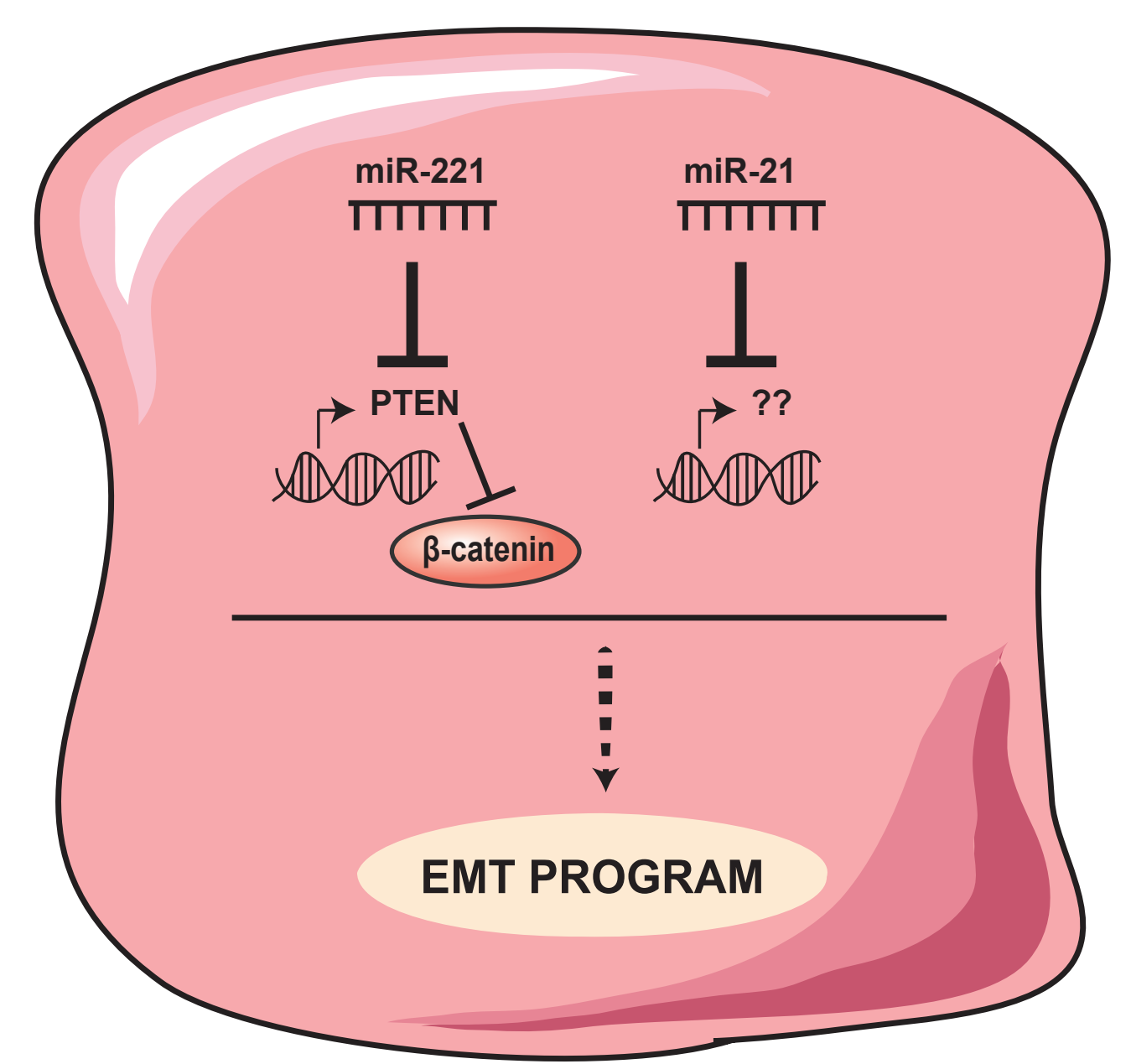


A. Myofibroblasts and Hepatic Stellate Cells

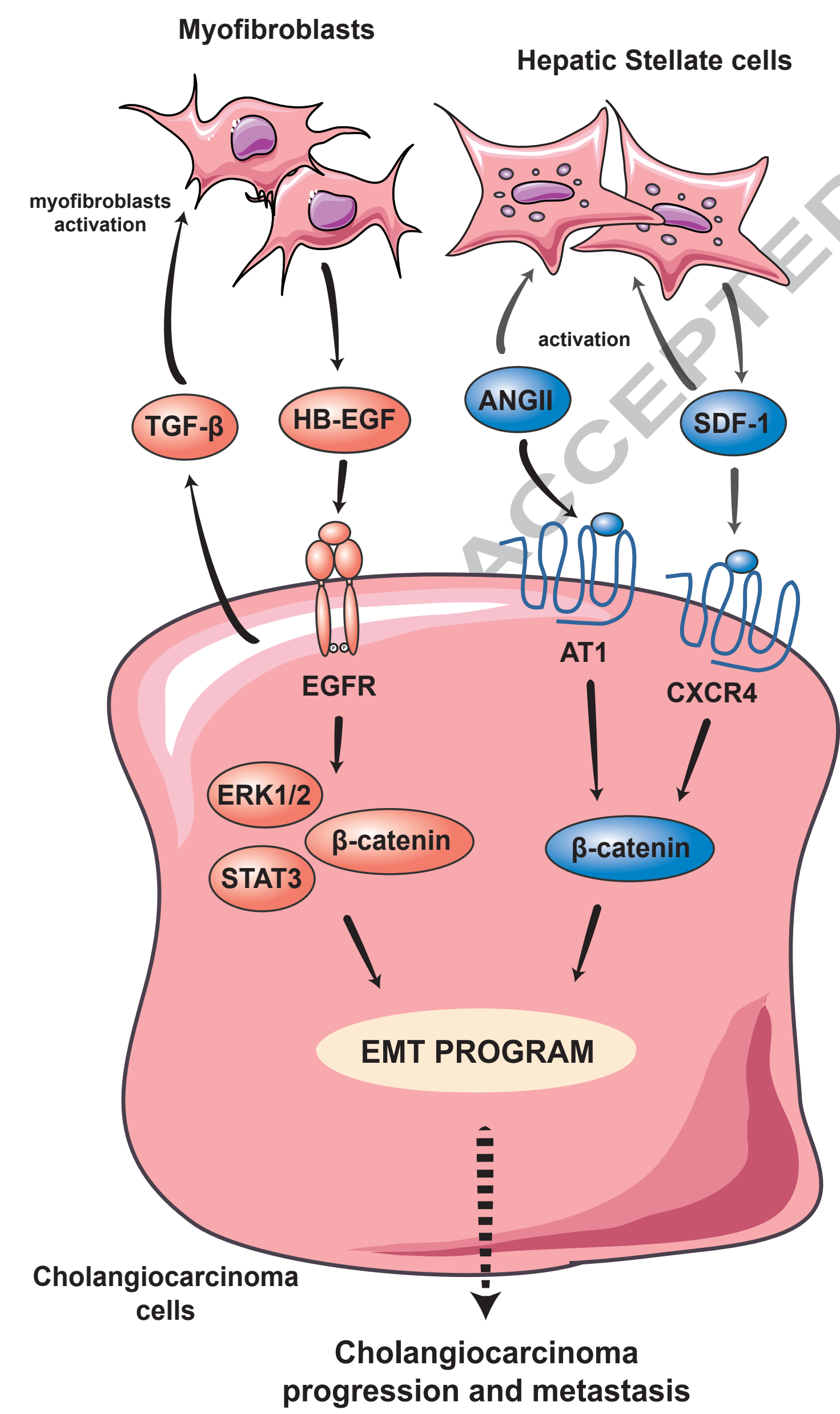

B. Tumor-Associated Macrophages and Mast Cells

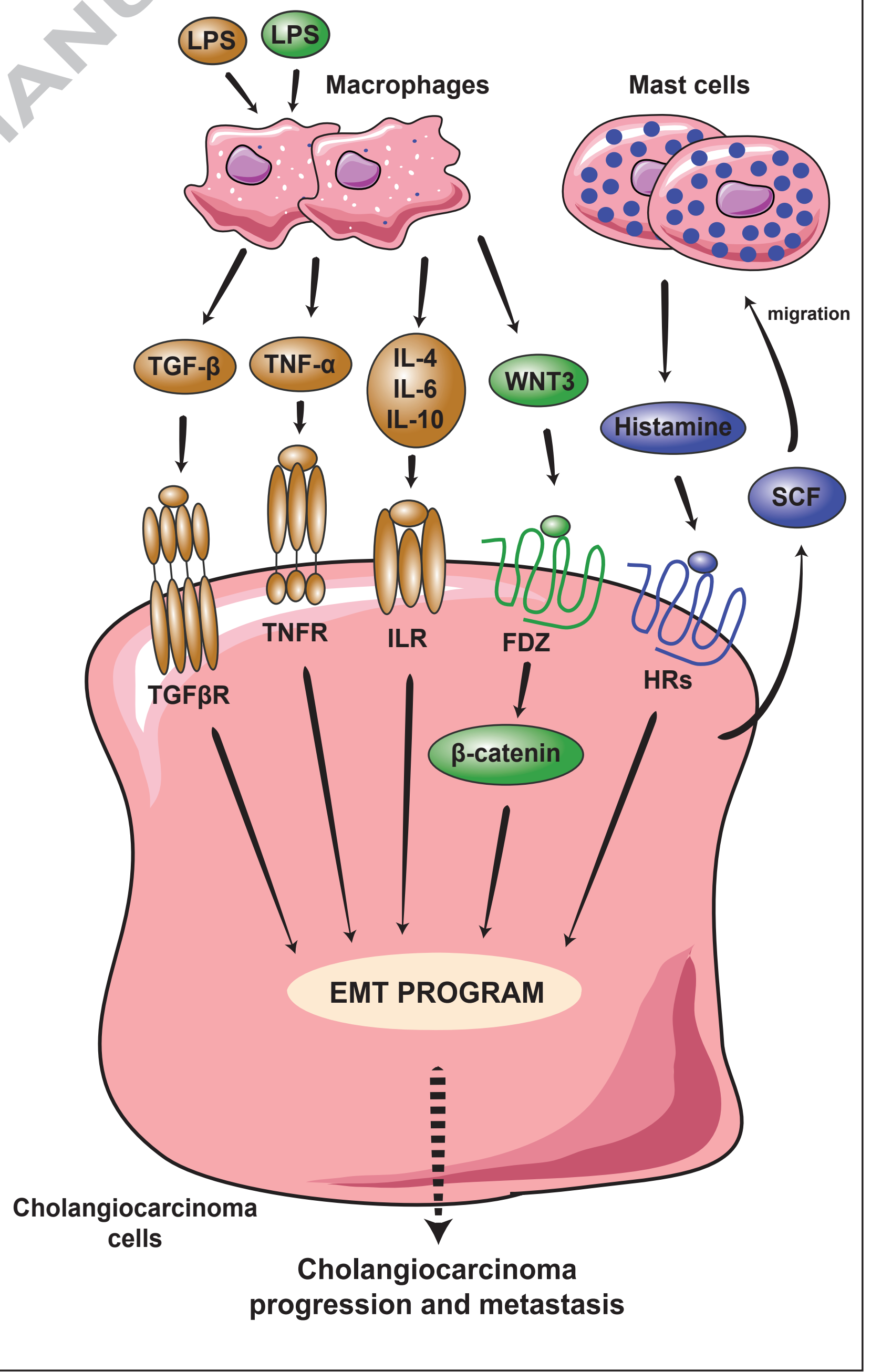

